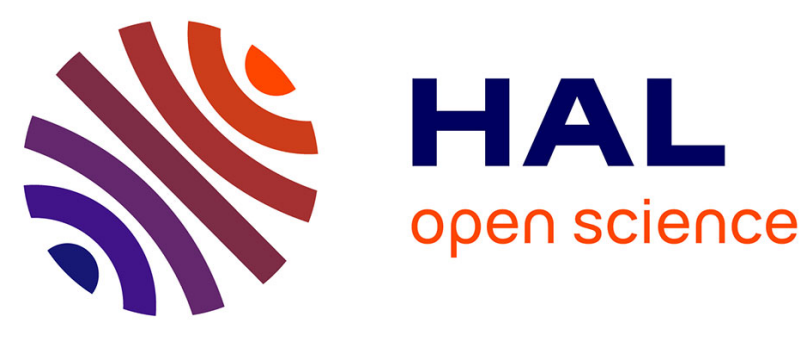

\title{
Cobalt Corroles with Bis-Ammonia or Mono-DMSO Axial Ligands. Electrochemical, Spectroscopic Characterizations and Ligand Binding Properties
}

Valentin Quesneau, Wenqian Shan, Nicolas Desbois, Steṕhane Brandes, Yoann Rousselin, Meddy Vanotti, Virginie Blondeau-Patissier, Mario Naitana, Paul Fleurat-Lessard, Eric van Caemelbecke, et al.

\section{To cite this version:}

Valentin Quesneau, Wenqian Shan, Nicolas Desbois, Steṕhane Brandes, Yoann Rousselin, et al.. Cobalt Corroles with Bis-Ammonia or Mono-DMSO Axial Ligands. Electrochemical, Spectroscopic Characterizations and Ligand Binding Properties. European Journal of Inorganic Chemistry, 2018, 2018 (38), pp.4265-4277. 10.1002/ejic.201800897 . hal-03481809

\author{
HAL Id: hal-03481809 \\ https://hal.science/hal-03481809
}

Submitted on 15 Dec 2021

HAL is a multi-disciplinary open access archive for the deposit and dissemination of scientific research documents, whether they are published or not. The documents may come from teaching and research institutions in France or abroad, or from public or private research centers.
L'archive ouverte pluridisciplinaire HAL, est destinée au dépôt et à la diffusion de documents scientifiques de niveau recherche, publiés ou non, émanant des établissements d'enseignement et de recherche français ou étrangers, des laboratoires publics ou privés. 


\title{
Cobalt Corroles with Bis-Ammonia or Mono-DMSO Axial Ligands. Electrochemical, Spectroscopic Characterizations and Ligand Binding Properties
}

\author{
Valentin Quesneau, ${ }^{[\mathrm{a}]}$ Wenqian Shan, ${ }^{[\mathrm{b}]}$ Nicolas Desbois, ${ }^{[\mathrm{a}]}$ Stéphane Brandès, ${ }^{[\mathrm{a}]}$ \\ Yoann Rousselin, ${ }^{[\mathrm{a}]}$ Meddy Vanotti, ${ }^{[\mathrm{c}]}$ Virginie Blondeau-Patissier, ${ }^{[\mathrm{c}]}$ Mario \\ Naitana, ${ }^{[a]}$ \\ Paul Fleurat-Lessard, ${ }^{[\mathrm{a}]}$ Eric Van Caemelbecke, ${ }^{[\mathrm{b}, \mathrm{d}]}$ Karl M. Kadish, ${ }^{*[\mathrm{~b}]}$ and Claude P. \\ Gros*[a]
}

\begin{abstract}
Four bis-ammonia ligated cobalt corroles and four mono-DMSO ligated cobalt corroles with different mesoaryl substituents on the macrocycle $\left(\mathrm{A}_{2} \mathrm{~B}\right.$ - and $\mathrm{A}_{3}$-corroles) were syn- thesized and investigated as to their electrochemical and spec- troscopic properties under different solution conditions. The complexation energies of the investigated cobalt corroles were theoretically calculated to illustrate the propensity of the cobalt center for pentacoordination or hexa-coordination with various axial ligands (DMSO, CO, py and $\mathrm{NH}_{3}$ ). The structure of one hexacoordinate bis- $\mathrm{NH}_{3}$ cobalt corrole complex was also deter- mined by X-ray diffraction.
\end{abstract}

\section{Introduction}

Metallocorroles are now an often-studied group of macrocycles because of their unique spectral and electrochemical properties and their potential applications as catalysts for a variety of reactions. Although corroles show many similarities with porphyrins, their distinctive structural, spectroscopic and photophysical properties as well as their specific coordination chemistry and particular chemical reactivity places these macrocycles in a distinctive position among members of the porphyrinoid family. ${ }^{[1]}$ Particularly, cobalt corroles exhibit a rich redox chemistry which depends on both the type of macrocycle and axial coordination at the cobalt metal center. ${ }^{[1 b]}$ We have shown that solvents such as DMSO or pyridine as well as diatomic molecules such as CO will strongly coordinate to the cobalt center of the neutral corrole, leading not only to changes in electron density at the metal ion, but also in some cases to a change of metal and ligand oxidation state. ${ }^{[2]}$ Electron-withdrawing groups anchored at the periphery of the macrocyclic core will also change electron density at the cobalt central metal ion, thus directly affecting the magnitude and degree of axial coordination. ${ }^{[3]}$

[a] Université de Bourgogne Franche-Comté, ICMUB (UMR CNRS 6302) 9, Avenue A. Savary, BP 47870, 21078 Dijon Cedex, France E-mail: claude.gros@u-bourgogne.fr, http://icmub.fr

[b] Department of Chemistry, University of Houston Houston, Texas, 77204- 5003, USA E-mail: kkadish@uh.edu, http://kadish.chem.uh.edu

[c] Department Time-Frequency, Institut FEMTO-ST (UMR CNRS 6174) Université de Bourgogne Franche-Comté 26, Chemin de l'épitaphe, 25030 Besançon Cedex, France

[d] Department of Chemistry, Houston Baptist University, 7502 Fondren Road, Houston TX 77074-3298, USA

Supporting information and $O R C I D(s)$ from the author(s) for this article are available on the WWW under https://doi.org/10.1002/ejic.201800897.
Recently, we reported the synthesis and electrochemical characterization of nitrophenyl-substituted cobalt corroles axially ligated with DMSO or pyridine molecules in their air-stable form. ${ }^{[2,3]}$ The current manuscript is an expansion of these studies and characterizes in greater detail the properties of cobalt corroles with a single DMSO axial ligand or two $\mathrm{NH}_{3}$ axial ligands in their air-stable form. It is worthy to note that the hexacoordinate bis-ammonia cobalt corroles can easily be converted into the tetra-coordinated derivatives as shown in Scheme 1. Removal of the two coordinated ammonia molecules can be accomplished either under vacuum at $80^{\circ} \mathrm{C}$ or by dissolving the complex in dichloromethane and bubbling $\mathrm{N}_{2}$ gas through the solution. A schematic representation of the investigated compounds is given in Scheme 2.

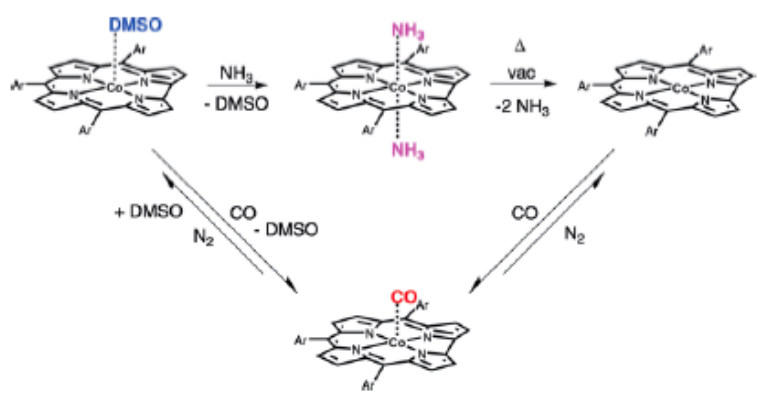

Scheme 1. From pentacoordinate to hexacoordinate cobalt corroles; easy access to the tetra-coordinated species.

We have been interested in the selective binding and detection of trace amounts of $\mathrm{CO}$ at the sub-ppm level in the atmosphere by using Surface Acoustic Wave (SAW) sensors functionalized by cobalt corroles. ${ }^{[4]}$ The pathway in Scheme 1 allows for a smooth and easy access to the active species (the tetra-coor- 


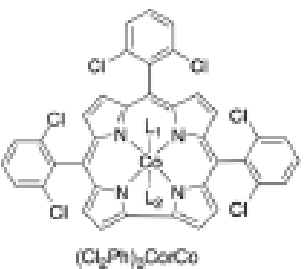

$\mathrm{NEH}_{2} ; L_{1}=L_{2}=\mathrm{NH}$ 10MSO: $L_{1}=D M S O, L_{2}=f$

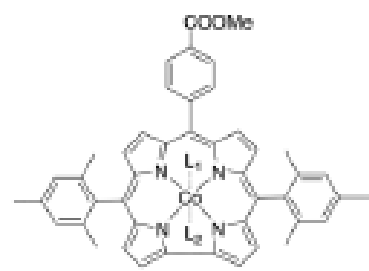

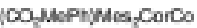

$2 \mathrm{NH}_{3}: \mathrm{L}_{1}=\mathrm{L}_{2}=\mathrm{NH}$ 2DMSO: $L_{1}=$ DMSO, $L_{2}=$ ?

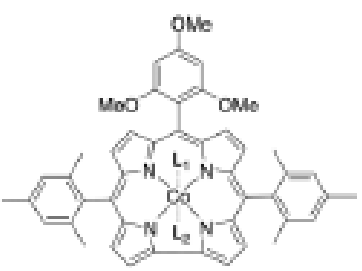

(IOMe) Paymesy Corco

$4 \mathrm{NH}_{3}: \mathrm{L}_{1}=\mathrm{L}_{2}=\mathrm{NH}_{3}$ 4DMSO: $L_{1}=$ DMSO, $L_{2}=$

$3 \mathrm{NH}_{2} ; \mathrm{L}_{1}=\mathrm{L}_{2}=\mathrm{NH}_{3}$ SDMSO: $L_{1}=$ DMSO, $L_{2}=\int$

Scheme 2 Structures of the inwestigsted bis-ammonia and mono-DMSO meso-aryl cobalt corroles.

dinated form of $\mathrm{A}_{3}$ - and/or $\mathrm{A}_{2} \mathrm{~B}$-cobalt corroles) which will bind $\mathrm{CO}$. Very recently, concentrations of $\mathrm{CO}$ as low as a few hundred ppb were measured by SAW sensors emphasizing the interest of such sensors for the detection of carbon monoxide [ब]

\section{Results and Discussion}

\section{Synthesis of Cobalt Corrole Complexes}

The eight cobalt corroles $\mathbf{1 D M S O}-\mathbf{4 D M S O}$ and $\mathbf{1} \mathbf{N H}_{\mathbf{3}}-\mathbf{4} \mathbf{N H}$, were prepared according to the synthetic procedure shown in Scheme 3. The $A_{s}$ and $A_{2} B$-free-base corroles $\mathbf{1 H}-4 \mathrm{H}$ were synthesized according to published procedures described by Gryko and co-workers, ${ }^{[5]}$ and metallated with $\mathrm{CO}(\mathrm{OAC})_{2}$ in DMSO to give the cobalt complexes 1DMSO-4DMsO, each with a single DMSO molecule as axial ligand. These mono-DMSO adducts were then treated with an aqueous ammonia solution to give the bis-ammonia derivatives $1 \mathbf{N H}_{3}-\mathbf{4} \mathrm{NH}_{3}$ in $79-94 \%$ yield.

\section{Spectroscopic Characterization}

The degree of axial coordination at the cobalt corrole center can be monitored by UV/Vis spectroscopy where large differences are seen between the four, five and six-coordinate forms of the compound. For example, as shown in Figure 1 for $1 \mathrm{CO}$ and 1DMSO, the two pentacoordinate cobalt corroles are characterized by a moderate absorption at 553 and $570 \mathrm{~nm}$ in the visible region of the spectrum. This spectral pattern contrasts with both the six coordinate $\mathbf{1} \mathbf{N H}_{\mathbf{y}}$ that is characterized by an intense absorption band at $616 \mathrm{~nm}$ and a split Soret band at 438 and $452 \mathrm{~nm}$ and the tetra-coordinate derivative 1 which lacks axial ligands and displays a much blue-shifted Soret band at $390 \mathrm{~nm}$ as seen in Figure 1.

In order to examine the lability of the DMSO axial ligands in the currently examined corroles, the UVNisible spectra of

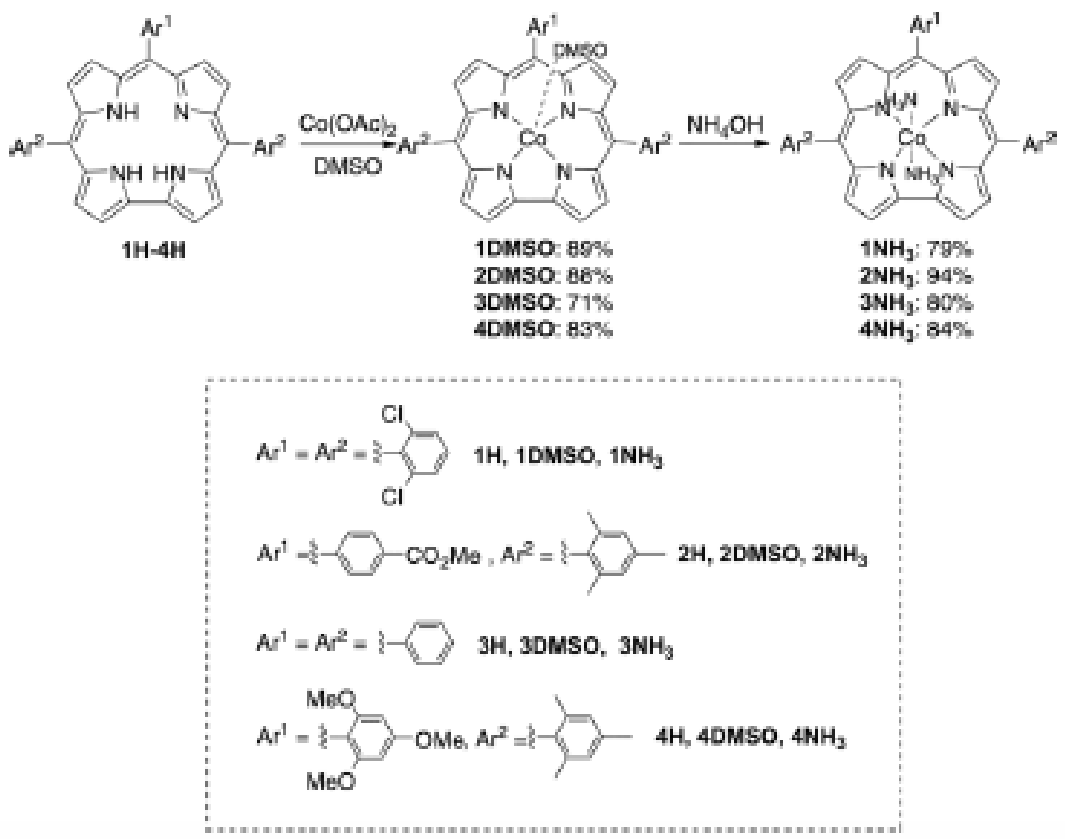

Scheme 3. Synthesis of mono-DNSO and bis-NH cobslt corroles. 

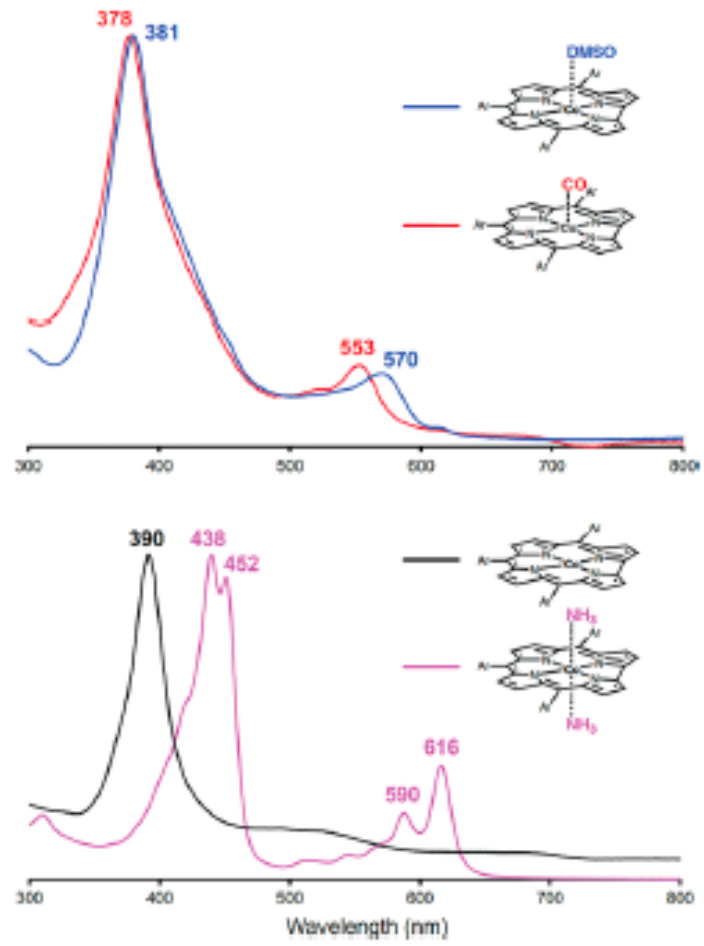

Figure 1. UNNisible spectra (in $\mathrm{OH}_{3} \mathrm{C}_{2}$ ) of cobsit corrole 1 as a function of the avial coordination (DMSO, $\mathrm{NH}_{2}, \mathrm{CO}$ or nothing).

1DMsO-4DMSO were measured at a concentration of $10^{-3} \mathrm{M}$ in both $\mathrm{CH}_{2} \mathrm{Cl}_{2}$ and DMSO containing $0.1 \mathrm{M}$ TBAP (Figure 2). In $\mathrm{CH}_{2} \mathrm{Cl}_{2}$ the spectra are characterized by a Soret band at 379$387 \mathrm{~nm}$ and a single less intense band at $562-566 \mathrm{~nm}$. There is also a shoulder on the Soret band at about $414-417 \mathrm{~nm}$. These spectra are similar to previously reported UV/Vis spectra for a related series of mono-DMSO ligated cobalt nitrophenylcorroles under the same solution conditions. ${ }^{[3]}$

Similar spectral patterns are seen for 2DMsO, 3DMso and 4DMSO in the two solvents but this is not the case for 1DMSO as seen in Figure 2. The spectrum in $\mathrm{CH}_{2} \mathrm{Cl}_{2}$ (Figure 2a) is assigned to the mono-DMSO adduct while in DMSO a mixture of the five- and six-coordinate derivatives are proposed to exist, the hexa-coondinate DMSO adduct having bands at 417, 442, 453 and $618 \mathrm{~nm}$ as described on the following pages. It should be noted that 1DMSO is the only cobalt corrole among the currently investigated compounds which possesses six electronwithdrawing substituents on the meso-phenyl rings, and this seems to facilitate the binding of a second DMSO molecule to the cobalt center of the neutral compound. Stronger pyridine binding constants were also earlier reported for cobalt corroles with electron-withdrawing substituents on the meso-phenyl rings $[M]$

UV/Visible spectra of the bis-ammonia complexes $\mathbf{1} \mathbf{N H}_{3}$ $4 \mathrm{NH}_{3}$ were also measured at a concentration of $1 \times 10^{-3} \mathrm{M}$ un-

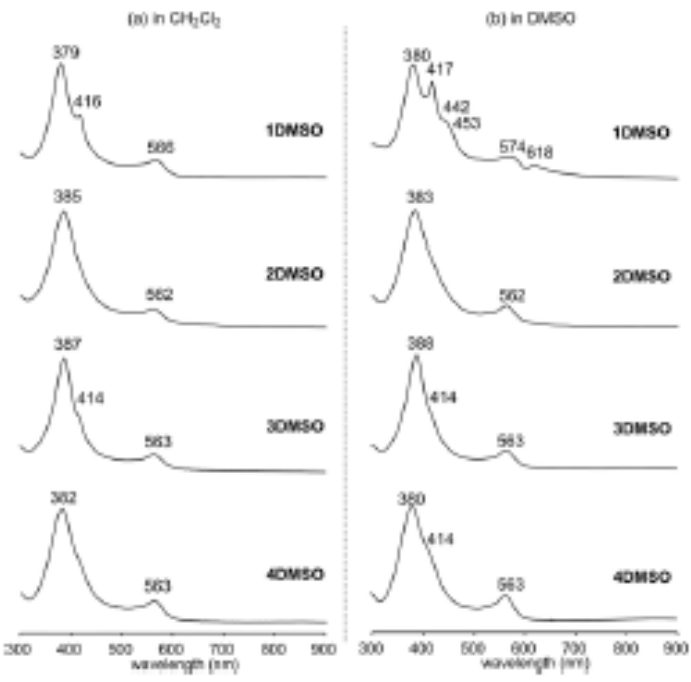

Figure 2. UVNisible spectrs of 1DMSO-4DMSO at $10^{-1} \mathrm{M}$ concentration in (a) $\mathrm{CH}_{2} \mathrm{C}_{2}$ and (b) DMSO containing $0.1 \mathrm{M}$ TEAP.

der two solution conditions, one being $\mathrm{CH}_{2} \mathrm{Cl}_{2}$ containing $0.1 \mathrm{M}$ TBAP and the other $\mathrm{CH}_{2} \mathrm{Cl}_{2}$ containing $0.1 \mathrm{M}$ TBAP and $1 \%(\mathrm{w} /$ v) $\mathrm{NH}_{4} \mathrm{OH}$ which produces $\mathrm{NH}_{3}$ in solution. Examples of the corrole spectra in the two solvents are shown in Figure 3 and a summary of the spectroscopic data for $1 \mathbf{N H}_{3}-\mathbf{4} \mathrm{NH}_{3}$ in $\mathrm{CH}_{2} \mathrm{Cl}_{2}$ containing $1 \% \mathrm{NH}_{4} \mathrm{OH}$ is given in Table 1. As seen in Figure 3 , $\mathrm{b}$, the UN/Visible spectrum of each bis- $\mathrm{NH}_{3}$ derivative is characterized by a split Soret band and two or three visible bands,

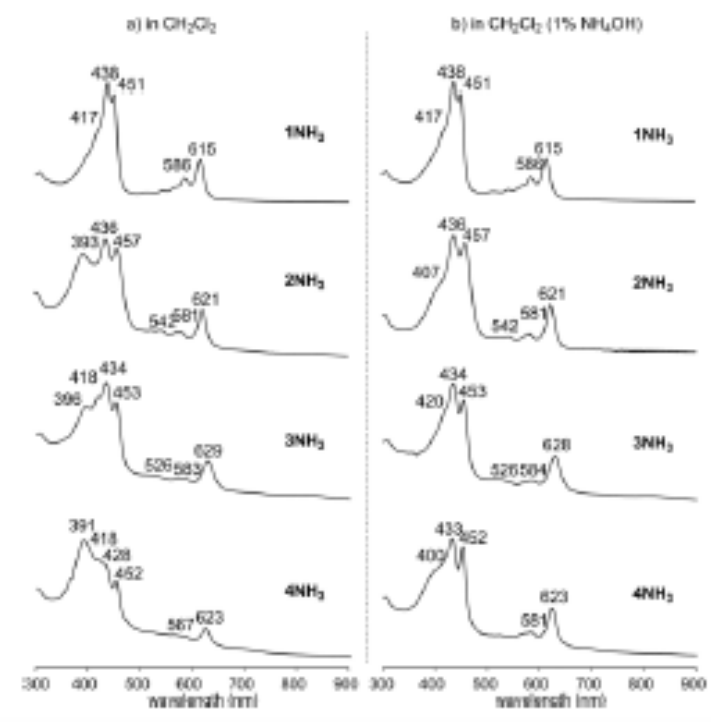

Figure 3. UVNisible spectra of $1 \mathrm{NH}_{2}-\mathbf{4} \mathrm{NH}_{3}$ at $10^{-1} \mathrm{M}$ concentration in a) $\mathrm{CH}_{2} \mathrm{C}_{2}$ and $\left.\mathrm{b}\right) \mathrm{CH}_{2} \mathrm{C}_{2}$ with $1 \%$ (w/v) $\mathrm{NH}_{4} \mathrm{OH}$ containing $0.1 \mathrm{~m}$ TBAP 
Table 1. UWVisible spectroscopic data of irmostigated cobslt corroles under different solution conditions.

\begin{tabular}{|c|c|c|c|c|c|c|c|c|}
\hline \multirow[t]{2}{*}{ Solution condition } & \multirow[t]{2}{*}{ Cpd } & \multicolumn{7}{|c|}{ Wavalength $\lambda_{\max } \mathrm{nm}\left(\mathrm{E} \times 10^{-4} \mathrm{M}^{-1} \mathrm{~cm}^{-1}\right)$} \\
\hline & & Sorst region & & & & visible rog & & \\
\hline \multirow[t]{3}{*}{$\mathrm{CH}_{2} \mathrm{O}_{2}$} & 1DMsO & $379(7.2)$ & $416(4.1)$ sh & & & $506(13)$ & & \\
\hline & 2DMsO & $385(6.4)$ & & & & $502(13)$ & & \\
\hline & 4DMsO & $382(7.2)$ & & & & $503(1.6)$ & & \\
\hline $\mathrm{CH}_{2} \mathrm{C}_{2}$ & $\mathrm{NNH}_{2}$ & & $417[5.0]$ & $438(B .3)$ & $451(7.6)$ & & $586(1.9)$ & $615(32)$ \\
\hline & $4 \mathrm{NH}_{2}$ & & $400(4.2)$ & $433(5.6)$ & $452(52)$ & & $581(1.4)$ & $623(2.4)$ \\
\hline
\end{tabular}

the most intense of which is located at $615-628 \mathrm{~nm}$ and is considered as a marker band for the hexacoordinate $\mathrm{CO}^{11}$ corrole. The overall spectral patterns of the $\mathbf{1} \mathbf{N H}_{3}$ to $\mathbf{4} \mathbf{N H}$, derivatives are similar to spectral patterns earlier reported for structurally related cobalt corroles containing two axially bound pyridine ligands. $|x|$

The same UV/Nis spectrum is obtained for $1 \mathrm{NH}_{3}$ in $\mathrm{CH}_{2} \mathrm{Cl}_{2}$ with and without $1 \% \mathrm{NH}_{4} \mathrm{OH}$, both spectra being essentially identical with spectra of the initial synthesized bis- $\mathrm{NH}_{3}$ adduct in toluene (see Exp. Sect.). In contrast, different spectral patterns are seen upon going from $\mathbf{2} \mathbf{N H}_{3}$ to $\mathbf{4} \mathbf{N H}_{3}$ in $\mathrm{CH}_{2} \mathrm{Cl}_{2}$ with and without $1 \% \mathrm{NH}_{4} \mathrm{OH}$. The largest variation between the two solution conditions is observed in the Soret region of the spectrum, where bands assigned to a five-coordinate corrole are observed for the bis- $\mathrm{NH}_{3}$ derivatives 2, 3 and $\mathbf{4}$ but not for compound 1. The fact that identical spectra are obtained for $1 \mathrm{NH}_{3}$ in $\mathrm{CH}_{2} \mathrm{Cl}_{2}$ with and without added $\mathrm{NH}_{4} \mathrm{OH}$ suggests that this corrole has a stronger affinity for $\mathrm{NH}_{3}$ than the other investigated derivatives and that dissociation of the bound $\mathrm{NH}_{3}$ axial ligands does not readily occur in $\mathrm{CH}_{2} \mathrm{Cl}_{2}$. This observation is consistent with the lower electron density of the $1 \mathbf{N H}_{3}$ macrocycle due to the electron-withdrawing halogen atoms on the meso-phenyl rings of the corrole and it is also consistent with the relative order of the pyridine binding constants to the mono-DMSO derivatives, as described below.

\section{Pyridine Binding Ability}

The relative intensity of the diagnostic six-coordinate absorption band at $615-623 \mathrm{~nm}$ for compounds $\mathbf{1} \mathbf{N H}$, to $\mathbf{4} \mathrm{NH}_{3}$ in Figure 3a follows the order $\mathbf{1} \mathbf{N H}_{3}>\mathbf{2} \mathbf{N H}_{3}>\mathbf{3} \mathbf{N H}_{3}>\mathbf{4} \mathbf{N H}_{3}$ and provides an approximate measure of the extent of $\mathrm{NH}_{3}$ dissociation from the bis- $\mathrm{NH}_{3}$ adducts in $\mathrm{CH}_{2} \mathrm{Cl}_{2}$ at a corrole concentration of $10^{-3} \mathrm{M}$. The band intensity follows the order $1>2>3$ $>4$ and this would also be the relative order of the $\mathrm{NH}_{3}$ binding strength for the examined bis- $\mathrm{NH}_{3}$ derivatives in the $\mathrm{CH}_{2} \mathrm{Cl}_{2}$ solvent.

We could not evaluate the magnitude of the $\mathrm{NH}_{y}$ binding constants to the four-coondinate corroles in the current study but we could measure binding constants for the stepwise addition of two pyridine molecules to the mono-DMSO adducts in $\mathrm{CH}_{2} \mathrm{Cl}_{2}$. This was done by monitoring changes in the UV/Visible spectra during a titration of each corrole with pyridine, giving results of the type shown in Figure 4 for the stepwise conversion of 1DMSO-4DMSO to their respective six-coordinate, bispyridine form. Equilibrium constants for addition of the first pyridine axial ligand to the mono-DMSO adducts were not determined due to the small differences in spectra between the initial corrole reactant and the mono-pyridine adduct but much larger spectral changes and well-defined log-log plots were obtained upon formation of the bis-pyridine derivatives as shown in Figure 4, b. The binding constant for addition of a second pyridine molecule to 1 DMSO was measured as $\log K_{2}=3.6$ and this $\log K_{2}$ value systematically decreased to $2.1,1.5$ and 1.1 for 2DMSO, 3DMso and 4DMSO, respectively. These values are given in Table 2 along with $\log K_{2}=2.6$ for addition of a second pyridine molecule to Mes_ConCo(py), as reported in an earlier study[y]

\section{MS Spectra of $1 \mathrm{NH}_{3}-4 \mathrm{NH}_{3}$ and 1DMSO-4DMSO}

Mass spectrometry utilizing different ionization modes (ESI and MALDI-TOF) was used to characterize the bis-ammonia and mono-DMSO complexes. In the case of MALDI-TOF analysis, the data gives in each case the cobalt corroles without any axial ligands, the $\mathrm{DMSO}$ and $\mathrm{NH}_{3}$ groups being lost under high vacuum during the preparation step, thus leading to the tetracoordinated cobalt complexes 1-4 (Figure S2a-h). In order to observe the labile ligands, we optimized the MS procedure in the ESI mode by directly injecting the compounds dissolved in a solution of ammonia or DMSO (see Exp. Sect.) and, under these conditions, the labile DMSO or $\mathrm{NH}_{3}$ axial ligands were both observed (see Figure \$2a-h) providing further evidence for formation of the penta- and hexacoordinate cobalt corrole complexes in the original synthesis.

\section{'H NMR, EPR and IR Charactertzation}

The effect of the meso-aryl substituents on the coondinating ability of the cobalt center of $\mathbf{1} \mathbf{N H}_{3}$ and $\mathbf{4} \mathbf{N H}$, was examined

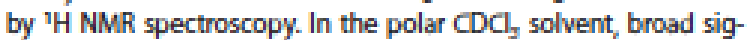
nals were obtained for $\mathbf{1} \mathrm{NH}_{3}$ which contains two electron-withdrawing $\mathrm{Cl}$ substituents on the meso-phenyl rings (Figure $5 \mathrm{c}$ ), but almost no signal is observed for $\mathbf{4} \mathbf{N H}$, which bears electron-donating substituents (Figure 5f). The lack of a diamag- 

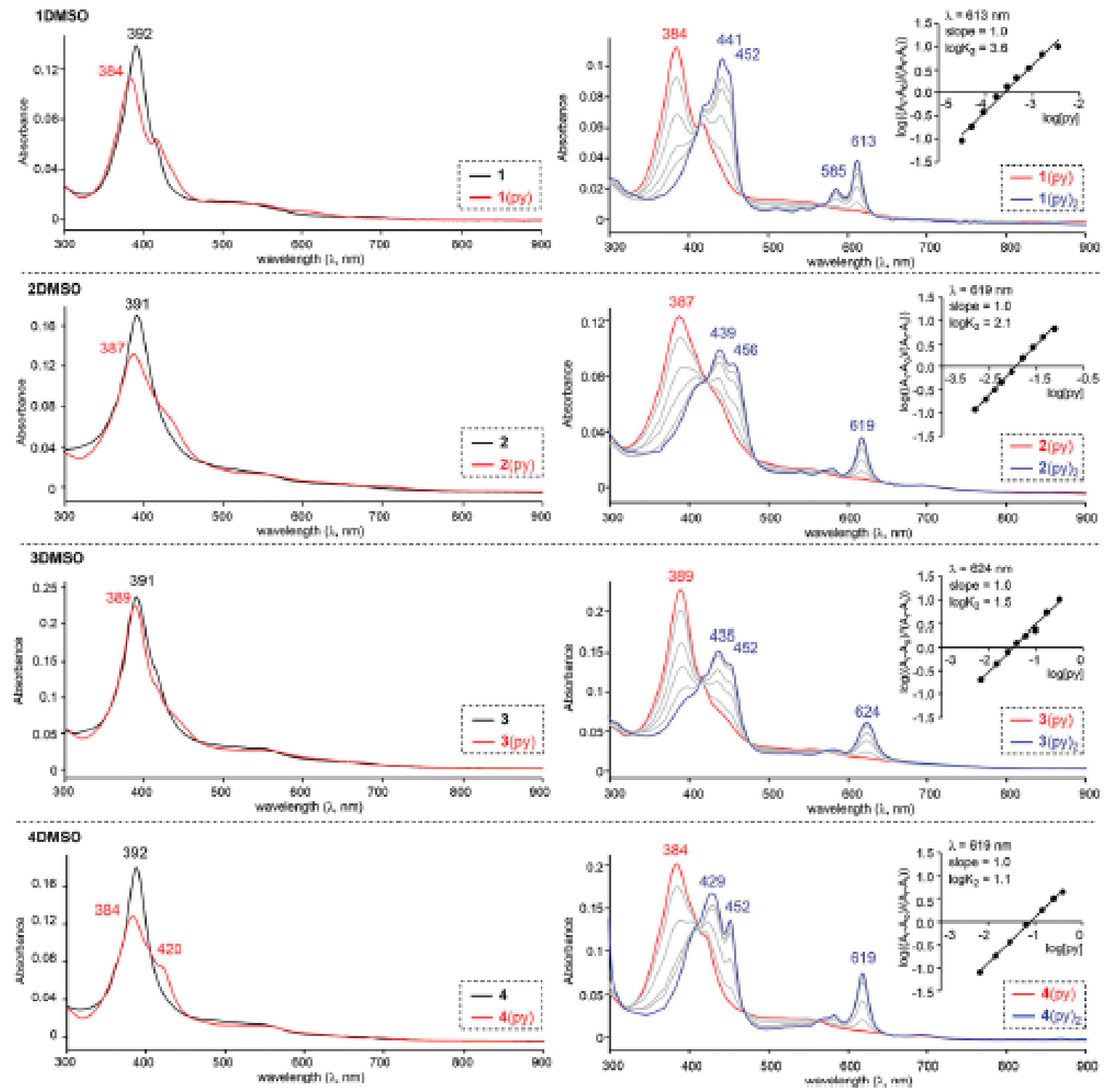

Figure 4. UNNisible spectrs changes of 1DMSO-4DMSO (at $\left.* 10^{-5} \mathrm{M}\right)$ in $\mathrm{CH}_{2} \mathrm{C}_{2}$ upon addition of pyridine to solution.

Table 2 Pyridine binding constants, $\log \mathrm{K}$, for cobslt corroles in $\mathrm{CH}_{2} \mathrm{C}_{2}$

\begin{tabular}{|c|c|c|c|}
\hline Compound & $\log K_{1}$ & $\log K_{2}$ & Reference \\
\hline$(p-C O O M a P h)(\operatorname{Mes})$ Corlo 2 & - & 2.1 & tw \\
\hline$\left(\mathrm{m}-\mathrm{NO}_{2} \mathrm{p}-\mathrm{FPh}\right)\left(\mathrm{p}-\mathrm{NO}_{2} \mathrm{Ph}\right)_{2} \mathrm{Cor} \mathrm{Cl}_{0}$ & - & 3.9 & 田 \\
\hline 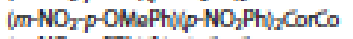 & - & 3.8 & $m$ \\
\hline$(\text { Mes) })_{1}$ Corco & 6.5 & 2.6 & $m$ \\
\hline
\end{tabular}

[a] $\mathrm{tw}=$ this work. 
netic spectrum for $\mathbf{4} \mathrm{NH}_{3}$ is consistent with a dissociation of one or both labile $\mathrm{NH}_{3}$ ligands in $\mathrm{CDCl}_{9}$, generating a paramagnetic form of the cobalt corrole due to the non-innocent character of the four- or five-coordinate species. ${ }^{[6]}$ However, when $\mathrm{NH}_{3}$ gas was bubbled into the NMR tube, broad signals appeared for $\mathbf{4} \mathbf{N H}_{\mathbf{3}}$ (Figure $5 \mathrm{e}$ ) indicating a mixture of electronic spin states for the cobalt ion $(S=0$, diamagnetic and $S=1$, paramagnetic), as well as some $S=1 / 2$ species probably due to traces of the corrole radical. ${ }^{[\mathrm{scc}]}$ This contrasts with the NMR spectrum of $\mathbf{1} \mathbf{N H}_{3}$ which exhibits sharp signals (Figure 5b) characteristic of a pure diamagnetic compound.

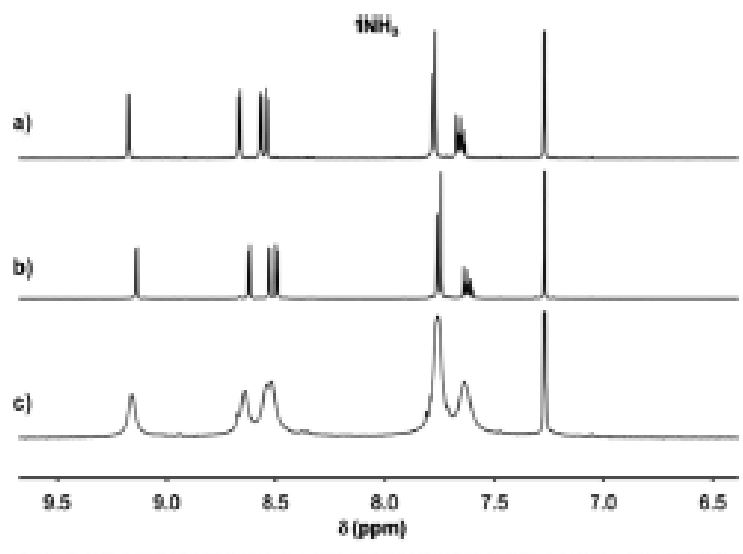

$4 \mathrm{NaH}_{3}$
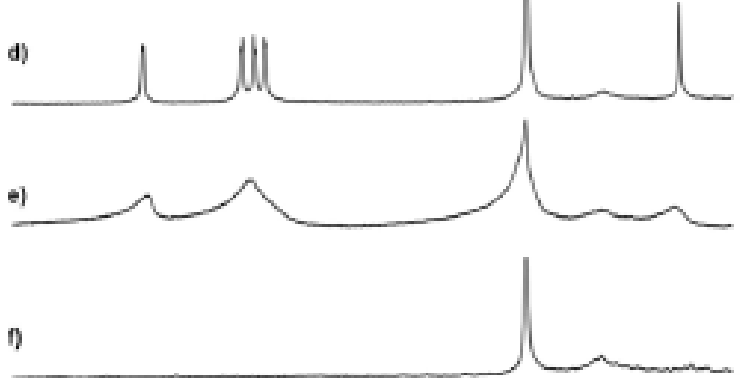

$\begin{array}{rrrrrrr}9.5 & 9.0 & 8.5 & \begin{array}{r}8.0 \\ 8(\mathrm{ppm})\end{array} & 7.5 & 7.0 & 6.5\end{array}$

Figure 5. " $\mathrm{H}$ NMR spectra of $1 \mathrm{NH}_{3}$ (top) and $\mathbf{4} \mathrm{NH}_{3}$ (bottom) in $\mathrm{CDC}_{3}$ before (c) and (f) and after addition of (b), (o) $\mathrm{NH}_{2}(\mathrm{~g})$ or (a), (d) $\mathrm{N}_{2} \mathrm{H}_{4} \mathrm{H}_{2} \mathrm{O}$.

In order to confirm the paramagnetic behavior of these complexes, EPR experiments were run on the electron-poor and electron-rich $1 \mathbf{N H}_{3}$ and $\mathbf{4} \mathrm{NH}_{3}$ complexes in toluene at $293 \mathrm{~K}$ (Figures $\$ 9$ and $\$ 10$ ), and this data should give a direct measurement of the electronic spin state. ${ }^{|k|}$ In both cases, the spectra (Figures S9a and S10a) have a radical-like pattern centered at $g=2.002$, with a small broadening of the single line (FWHH = $10 \mathrm{G}$. This central line can be assigned to a radical impurity due to over-oxidation of the corrole that is frequently observed for these type of macrocycles. ${ }^{[1, s t b]}$
No other transition is shown for $\mathbf{1} \mathbf{N H}_{3}$, indicating either that the cobalt corrole is mainly in a diamagnetic $\mathrm{Co}^{\mathrm{II}}$ form, or that it possesses a strongly antiferromagnetic $S=0$ spin state and a Coll-corrole $\mathrm{e}^{2-}$ formulation. The assignment is favored after addition of $\mathrm{NH}_{4} \mathrm{OH}$, since two broad signals with low intensities assigned to the excited triplet state now appear on either side of the radical signal. Under these conditions, the hexacoordinate complex with two $\mathrm{NH}_{3}$ axial ligands is predominant in solution (see UVNisible data). It should also be noted that the intensity of the radical signal strongly decreases after addition of $\mathrm{NH}_{4} \mathrm{OH}$, suggesting on one hand the formation of a more diamagnetic hexacoordinate complex, and on the other a partial over-oxidation of the pentacoondinate corrole formed after loss of one $\mathrm{NH}_{2}$ ligand from the bis-ammonia complex when it is dissolved in toluene (Figure S9a). In addition, the low intensity of the triplet state agrees with a large singlet-triplet gap, inducing a weak population of the excited triplet state. This result adds strong support to assignments from the NMR spectra which show formation of a diamagnetic $\mathbf{1} \mathbf{N H}_{3}$ complex dissolved in solutions containing $\mathrm{NH}_{4} \mathrm{OH}$ or $\mathrm{N}_{2} \mathrm{H}_{4}$. Finally, it should be noted that hydrazine can act as a mild reducing agent which would remove all traces of any paramagnetic corrole radical.

A rather similar situation was observed for $\mathbf{4} \mathbf{N H}_{\mathbf{3}}$ (Figure $\$ 10 a, b)$ which is characterized by a radical spectrum centered at $g=2.002$, but flanked with two strong signals at $g=\mathbf{2 . 0 1 5}$ and 1.986 assigned to the triplet state resulting from ferromagnetic coupling between the cobalt(III) ion and the ion radical for the Coll-corrole ${ }^{2-}$ formalism. In addition, the spectrum is devoid of any resolvable hyperfine interactions due to the strongly delocalized spin system. As the intensity of the spectrum is directly correlated to the relative population of the triplet state, one can anticipate a lower singlet-triplet gap compared to $1 \mathrm{NH}_{3}$ and an overall picture of a singlet ground state with the thermally accessible triplet state.

The addition of $\mathrm{N}_{2} \mathrm{H}_{4}$ (Figure S10c) resulted in a loss of the radical signal and only the two signals assigned to the triplet state are preserved. This result is in agreement with the NMR spectroscopic data of $\mathbf{4 N H}$, that show more resolved signals after addition of hydrazine (Figure $5 \mathrm{~d}$ ). The rather broad NMR lines of $\mathbf{4} \mathrm{NH}_{3}$ compared to $\mathbf{1} \mathrm{NH}_{\mathbf{y}}$ can also be attributed to a residual paramagnetism of the complex due the more accessible triplet state.

Moreover, the hexacoordinate bis- $\mathrm{NH}_{\text {, }}$ complexes could be formed directly from the pentacoordinate mono-DMSO derivatives by adding ammonia gas into the NMR tube in order to displace the coordinated DMSO. After the displacement has occurred, a peak for one free DMSO molecule is seen in the spectrum at $\delta=2.60 \mathrm{ppm}$ and the two $\mathrm{NH}_{3}$ ligands appear in the anisotropic ring current of the corrole at around -6.60 . Integration of the NMR signals for both DMSO and $\mathrm{NH}_{3}$ peaks confirms the assigned penta- and hexa-coordination (see Figure S3e-g).

The axial coordination of $\mathrm{NH}_{2}$ was also observable by infrared spectroscopy. The infrared spectra of $\mathbf{1} \mathbf{N H}_{\mathbf{3}}-\mathbf{4} \mathbf{N H}_{\mathbf{3}}$ are characterized by antisymmetric and symmetric $\mathrm{NH}_{3}$ stretching vibrations at around 3260 and 3360 ppm, respectively (see Figure S6 and Table 52). 
Penta- vs. Hexa- Coordination of Cobalt Corroles Examined by DFT Computational Study

Cobalt corroles are known to bind two molecules of pyridine but only a single molecule of carbon monoxide ${ }^{[7]}$ or DMSO [2] In the current study, we observed that the examined cobalt corroles would easily bind two molecules of $\mathrm{NH}_{3}$ and this was theoretically examined for the case of $\left(\mathrm{Cl}_{2} \mathrm{Ph}\right)_{3} \mathrm{Con} \mathrm{Co}_{0} \mathbf{1}$, which was also modelled with respect to the binding of $\mathrm{CO}, \mathrm{DMSO}$, pyridine and $\mathrm{NH}_{\mathrm{y}}$. The geometry of the cobalt corrole $\left(\mathrm{Cl}_{2} \mathrm{Ph}\right)_{3} \mathrm{CorCo} 1$ was optimized, both as the four-coordinate complex and as five- and six-coordinate derivatives complexed with one and two axial ligands, respectively. The axial coordination processes are described by Equation (1) and Equation (2), where $X$ represents the axial ligand and $\Delta G$ is the complexation free energy. The calculated complexation free energies are listed in Table 3.

$$
\begin{aligned}
& \left(\mathrm{Cl}_{2} \mathrm{Ph}\right)_{3} \mathrm{CorCo}+\mathrm{X} \leftrightarrows\left(\mathrm{Cl}_{2} \mathrm{Ph}\right)_{3} \mathrm{CorCo} \mathrm{X} \rightarrow \Delta_{7} \mathrm{G}_{1}(X) \\
& \left(\mathrm{Cl}_{2} \mathrm{Ph}\right)_{3} \mathrm{CorCoX}+\mathrm{X} \leftrightharpoons\left(\mathrm{Cl}_{2} \mathrm{Ph}\right)_{3} \mathrm{CorCoX} \mathrm{X}_{2} \rightarrow \Delta_{2} \mathrm{G}_{2}(X)
\end{aligned}
$$

A negative value of $\Delta_{1} G_{2}(X)$ indicates that hexa-coondination is favored, while a positive value indicates complexation of only a single axial ligand at the cobalt center. As seen in Table 3 , the formation of hexacoondinate complexes for $\left(\mathrm{Cl}_{2} \mathrm{Ph}\right)_{5} \mathrm{CorCo} \mathbf{1}$ is favorable with $\mathrm{NH}_{3}$ or pyridine ligands, but unfavorable with both $\mathrm{CO}$ and DMSO, a result in agreement with the experimental data. ${ }^{[]]}$However, it should be noted that the theoretical value of $\Lambda_{r} G_{2}$ (DMSO) is close to 0 , a result which may explain why the characteristic UV/Nisible spectral pattern of a bis-DMSO complex is observed for 1DMSO in the DMSO solvent at a $10^{-3} \mathrm{M}$ concentration of the corrole (Figure $2 \mathrm{~b}$ ).

In order to theoretically study the effect of different mesophenyl substituents on the $\mathrm{NH}_{3}$ binding ability of the corroles, we also calculated the complexation free energies of 1-4 with $\mathrm{NH}_{3}$. These values are given in Table 4 and show that the bisammonia complex is in each case greatly favored, with large negative values ranging from -12.2 to $-9.3 \mathrm{kcal} / \mathrm{mol}$. The data in Table 4 show that the binding strength with $\mathrm{NH}_{3}$ follows the order: $1>2>4>3$, which is slightly different from the order predicted by measurements of the six-coondinate marker band in UV/Visible spectra for the same compounds, namely $1>2>$ $3>4$.

SIngle Crystal X-ray Diffraction Studies of Bis-Ammonla Cobalt Corrole $1 \mathrm{NH}_{3}$

Single crystals of corrole $\mathbf{1} \mathbf{N H}$, were grown by slow evaporation of a $\mathrm{CH}_{2} \mathrm{Cl}_{2}$ /hexane mixture of $1 \mathrm{NH}_{3}$ and gave the structure shown in Figure 6. Details about the structure are given in the Sl.

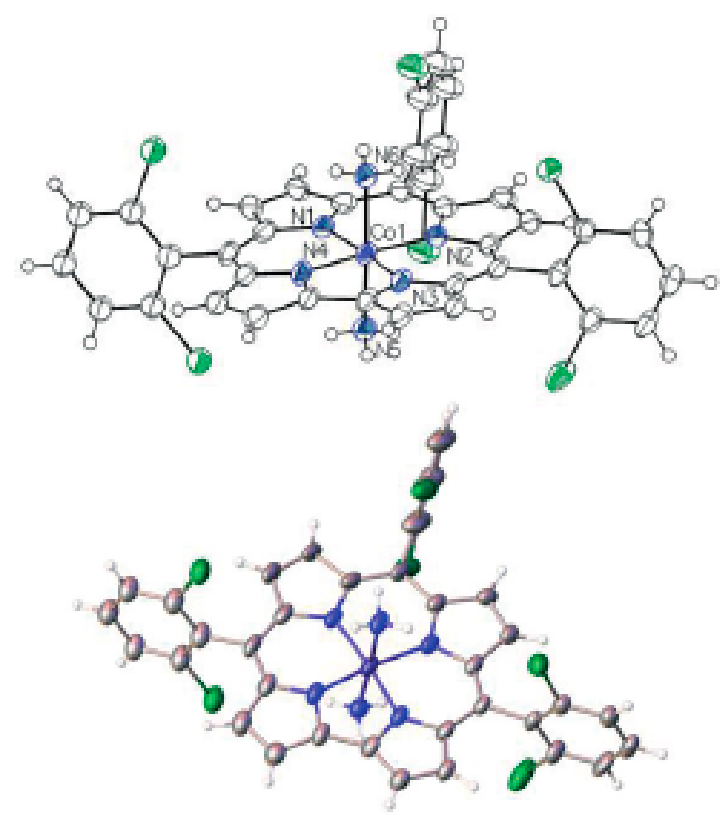

Figure a. ORTEP view of compound $\mathbf{1} \mathrm{NH}_{3}$. Themal ellipsoids are drawn at the $50 \%$ perabability lewel. Solvent and disondered part are omittod for darity.

\begin{tabular}{|c|c|c|c|}
\hline Cobalt corrole & Ligand $X$ & $\begin{array}{l}\text { Complexation frese energies [kcal/mol] } \\
A, G_{1}\left(D_{1}\right)\end{array}$ & $\Lambda_{r} G_{2}(X)$ \\
\hline $\begin{array}{l}\mathrm{INH}_{2} \\
\mathrm{IPy}\end{array}$ & $\begin{array}{l}\mathrm{NH}_{2} \\
\text { Pyridine }\end{array}$ & $\begin{array}{l}-4.7 \\
-9.0\end{array}$ & $\begin{array}{l}-122 \\
-115\end{array}$ \\
\hline 100 & co & -2.3 & +9.4 \\
\hline 1DMso & DMSOO'] & -3.3 & +1.4 \\
\hline
\end{tabular}

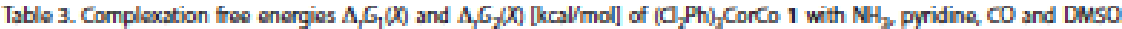

[a] $5=1$ is the most stable state for these complewes.

\begin{tabular}{|c|c|c|c|}
\hline Compound & Ligand $X$ & $\begin{array}{l}\text { Complexation froe energies [kcal/mol] } \\
A, G_{1}(X)\end{array}$ & $\Delta, G_{2}(x)$ \\
\hline$\left(C_{2} P h\right)_{]}$Corco 1 & $\mathrm{NH}_{2}$ & -4.7 & -122 \\
\hline (COONoPh) Mes, $\mathrm{CorCO}_{2}$ & $\mathrm{NH}_{2}$ & -3.1 & -10.0 \\
\hline (Phitacorco 3 & $\mathrm{NH}_{2}$ & -45 & -93 \\
\hline$\left[\mathrm{OM}_{2} \mathrm{Ph}_{1}\right] \mathrm{Mes}_{2} \mathrm{CorCl} 4$ & $\mathrm{NH}_{2}$ & -2.9 & -9.7 \\
\hline
\end{tabular}

Table 4. Complexation free energies $\Lambda_{1} G_{1},(X)$ and $\Lambda_{1} G_{2}(X)$ [kcal/mol] of cobalt corroles 1-4 with $\mathrm{NH}_{2}$. 
Compound $1 \mathrm{NH}_{3}$ crystallizes in a $\mathrm{P}_{2} / \mathrm{c}$ centrosymmetric group. The asymmetric unit is composed of a cobalt corrole with two disordered dichlorophenyl units over two positions and one disondered hexane molecule (see SI). The cobalt complex is hexacoordinate with four nitrogen atoms of the corrole unit and two axial ammonia ligands which are bound to the cobalt center in an apical position. Thus, this complex adopts an octahedral geometry with a typical Oh type symmetry.

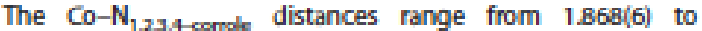
$1.908(6) \hat{A}$, values almost identical to those reported for the structure of vitamin B12 [a] i.e. between $1.887 \dot{A}$ and $1.912 \dot{A}$. The axial Co- $\mathrm{NH}_{3}$ distances of 1.964(6) $\bar{A}$ and 1.974(6) $\AA$ are

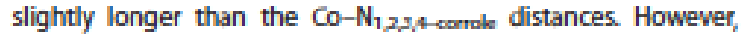
the values are still of the same order of magnitude as in the $\mathrm{Co}^{\mathrm{III}}-\mathrm{NH}_{y}$ complex $1.961(20) \dot{A}$, and are shorter than the cobaltpyridine distances for the same type of compound, 1.981$1.990(2) \hat{A}^{[D]}$ The corrole complex has a planar geometry with a maximum deviation from the mean plane of $0.13 \dot{A}$ for the C36 atom. The crystalline stacking is governed by intermolecular hydrogen bonds between the $\mathrm{NH}_{3}$ and the $\mathrm{Cl}$ groups of the corrole (ortho-dichlorophenyl substituents), thus forming a molecular wire bonded by hydrogen bonds (Figure \$2).

\section{Electrochemistry}

Redox properties of the synthesized corroles were investigated by cyclic voltammetry under different solution conditions. As previously demonstrated for a related series of derivatives, ${ }^{[1]}$ the synthesized mono-ligated DMSO cobalt corroles are invariably characterized by facile and reversible one-electron reductions in $\mathrm{CH}_{2} \mathrm{C}_{2}$ or DMSO (Figure 7 and Figure 57 ). This contrasts with what is seen for the hexacoordinate bis-pyridine derivatives where the first reduction in pyridine is irreversible and occurs at much more negative potentials. ${ }^{[x]}$ The difference in redox behavior between what is seen in $\mathrm{CH}_{2} \mathrm{Cl}_{2}$, DMSO or pyridine was explained as being due to a different site of electron transfer and a different electronic configuration of the redox active form of the corrole in solution, the mono-DMSO adducts being assigned as containing a Coll center and a non-innocent easily reduced macrocyclic ligand in $\mathrm{CH}_{2} \mathrm{Cl}_{2}$ or DMSO as compared to a $\mathrm{CO}^{11}$ center and a hard to reduce innocent macrocyclic ligand in pyridine where the first reduction involves a metal-centered $\mathrm{CO}^{\prime \prime} / \mathrm{CO}^{\mathrm{I}}$ process followed by a loss of one or both axial ligands after electron transfer. In other words, the reversibility of the first reduction process and the small electronic effect of the ligand on the potential values are in accordance with a Coll center and a non-innocent macrocycle.

The difference in axial coordination and ligand innocence or non-innocence also manifests itself in a difference of half-wave potentials for the first one-electron oxidation, this process being easiest (more negative potential) for oxidation of the cobalt bis-pyridine derivatives in pyridine and harder (more positive potential) for oxidation of the four- or five-coordinate cobalt corroles in $\mathrm{CH}_{2} \mathrm{Cl}_{2}$ or DMSO! ${ }^{[x]}$

We anticipated observing facile one-electron reductions for the newly synthesized mono-DMSO derivatives in the current study and this is indeed the case as shown by the cyclic voltammograms measured in DMSO (Figure 7) or $\mathrm{CH}_{2} \mathrm{Cl}_{2}$ (Figure 57 ).
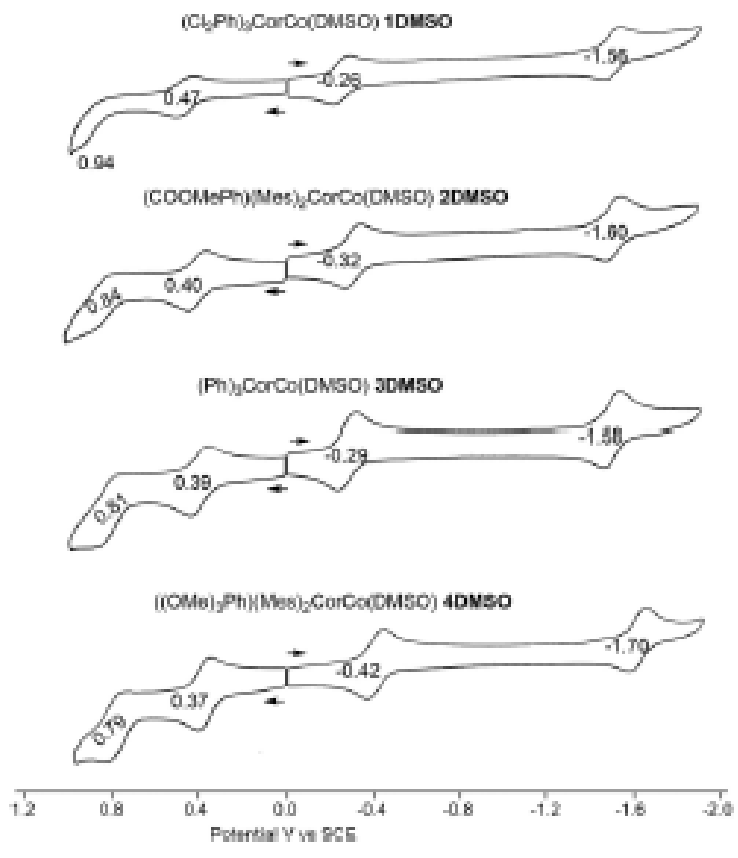

Figure 7. Cyclic voltammograms of cobalt corrole complexes 1DMSO4 DMSO $\left(0,10^{-2} \mathrm{M}\right.$ ) in DMSO containing $0.1 \mathrm{~N}$ TEAP.

1DMSO-4DMSO in DMSO (Figure 7) undergoes two reductions and two oxidations within the negative and positive potential limits of the solvent. The first one-electron reduction is located at $E_{1 / 2}=-0.26$ to $-0.42 \mathrm{~V}$ and the second at -1.56 to $-1.70 \mathrm{~V}$. The first one-electron oxidation ranges from $E_{1 / 2}=0.37$ to $0.47 \mathrm{~V}$ depending upon the specific meso-substituents. In addition, the absolute potential difference between the first reversible reduction and the first reversible oxidation of each compound (the HOMO-LUMO gap) varied from 0.72 to $0.79 \mathrm{~V}$ in DMSO, a range of values slightly smaller than the measured HOMO-LUMO gaps in $\mathrm{CH}_{2} \mathrm{Cl}_{2}$ where the potential separation ranges from 0.75 to $0.87 \mathrm{~V}$ (See examples of cyclic voltammograms in Figure S7 and summary of half-wave potentials in Table 5).

The binding of $\mathrm{NH}_{3}$ to the neutral and singly oxidized cobalt corroles $\mathbf{1}$ to $\mathbf{4}$ is stronger than the binding of DMSO to the same series of compounds in $\mathrm{CH}_{2} \mathrm{Cl}_{2}$ and this is reflected in large negative shifts of potential for the first one-electron abstraction, the measured $E_{1 / 2}$ values ranging from $0.30 \mathrm{~V}$ for $\mathbf{1} \mathrm{NH}_{3}$ to $0.05 \mathrm{~V}$ for $\mathbf{4} \mathrm{NH}_{3}$ as seen in Figure $\mathbf{8}$ (and Figure $\mathbf{S 8}$ ). Like potentials for electron abstraction from the mono-DMSO adducts, the measured half-wave potentials for oxidation of the bis- $\mathrm{NH}_{3}$ derivatives shift negatively with increasing electrondonating character of substituents on the three meso-phenyl rings of the macrocycle. However, it should be noted that the substituent effect of the meso-phenyl groups is larger for the bis- $\mathrm{NH}_{3}$ ligated $\mathrm{Co}^{\mathrm{Ill}}$ corroles than for the five-coordinate derivatives (perhaps containing a $\mathrm{CO}^{\prime}$ center and a non-innocent ligand), resulting in an increasing difference in $E_{1 / 2}$ values between the first oxidation of the same corrole with different axial 
Table 5. Half-wave or peak potentials ( $E_{12}$ or $E_{\mathrm{p}} \mathrm{V}$ v. SCE) for reductions and the first two oxidations of the cobalt corroles in different solution conditions containing $0.1 \mathrm{M}$ TBAP (sweep rate: $100 \mathrm{mV} / \mathrm{s}$ ).

\begin{tabular}{|c|c|c|c|c|c|c|c|}
\hline \multirow{2}{*}{$\begin{array}{l}\text { Solution condition } \\
\mathrm{CH}_{4} \mathrm{C}_{2}\end{array}$} & \multirow{2}{*}{$\begin{array}{l}\text { Cpd } \\
1 D M S 0\end{array}$} & \multicolumn{6}{|c|}{ Potentials ( $V$ ve SCE) } \\
\hline & & & 0.99 & 0.71 & -0.15 & & $-1.03^{2 x}$ \\
\hline & 2DMsO & & 0.86 & 0.62 & -0.20 & & $-1.6 \theta^{2}$ \\
\hline & 3DMsO & 11.48 & 0.83 & 0.64 & -0.11 & & $-1.02 z^{2}$ \\
\hline & $40 \mathrm{MSO}$ & 11.45 & 0.88 & 0.60 & -0.27 & & -1.78 \\
\hline \multirow[t]{4}{*}{ DMsO } & 1DMso & & $0.94^{|x|}$ & 0.47 & -0.26 & & -156 \\
\hline & 20MSO & & 0.84 & 0.40 & -0.32 & & -1.60 \\
\hline & 3DMSO & & 0.81 & 0.39 & -0.29 & & -1.58 \\
\hline & 4DMSO & & 0.79 & 0.37 & -0.42 & & -170 \\
\hline \multirow[t]{4}{*}{$\mathrm{CH}_{2} \mathrm{C}_{2}$} & $1 \mathrm{NH}_{\mathrm{n}}$ & 1174 & 0.92 & 0.30 & -0.07 & -1.08 & $-1.62^{|2|}$ \\
\hline & $2 \mathrm{NH}_{3}$ & 11.49 & 0.74 & 0.14 & -0.19 & -1.29 & -1.68 \\
\hline & $3 \mathrm{NH}_{3}$ & 11.44 & 0.68 & 0.11 & $-0.14^{\mathrm{M} / \mathrm{I}}$ & -1.21 & $-1.6 z^{2}$ \\
\hline & $4 \mathrm{NH}_{\mathrm{a}}$ & 11.45 & 0.68 & 0.05 & -0.26 & -1.40 & $-1.78^{2}$ \\
\hline \multirow{4}{*}{$\mathrm{CH}_{4} \mathrm{C}_{2}\left(w^{\prime} \mathrm{v} 1 \% \mathrm{NH}_{4} \mathrm{OH}\right)$} & $1 \mathrm{NH}_{\mathbf{a}}$ & & - & - & - & - & - \\
\hline & $2 \mathrm{NH}_{3}$ & & 0.74 & 0.14 & -0.19 & & -1.000 \\
\hline & $3 \mathrm{NH}_{3}$ & & 0.64 & 0.10 & $-0.23^{\mathrm{an}}$ & -1.21 & $-1.64^{[x]}$ \\
\hline & $4 \mathrm{NH}_{2}$ & & 0.09 & 0.05 & -0.26 & & $-1.7 g^{|x|}$ \\
\hline
\end{tabular}

ligands, from $170 \mathrm{mV}$ in the case of compound $1(0.47 \mathrm{~V}$ in DMSO and $0.30 \mathrm{~V}$ in $\mathrm{CH}_{2} \mathrm{C}_{2}$ ) to $320 \mathrm{mV}$ for compound 4 (0.37 vs. $0.05 \mathrm{~V}$ ).

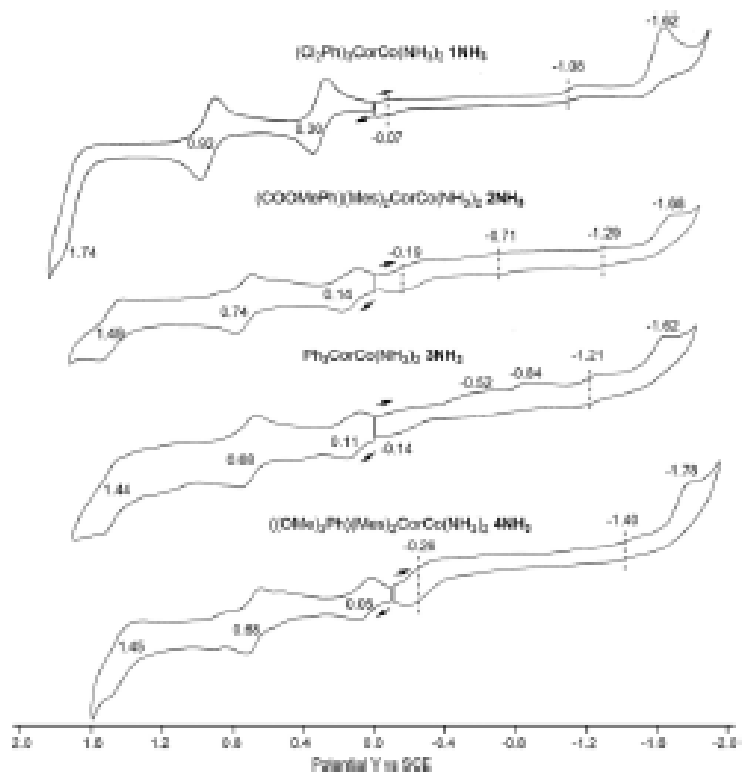

Figure 8. Cydic voltammograms of cobsit corrole complexes $\mathbf{i N H}_{2}-\mathbf{4} \mathrm{NH}_{6}$ (* $10^{-2} \mathrm{M}$ ) in $\mathrm{OH}_{2} \mathrm{Cl}_{2}$ containing $0.1 \mathrm{M}$ TBAP.

The oxidation of $(\mathrm{Cor}) \mathrm{Co}\left(\mathrm{NH}_{3}\right)_{2}$ to $\left[(\mathrm{Cor}) \mathrm{Co}\left(\mathrm{NH}_{3}\right)_{2}\right]^{+}$occurs in the absence of coupled chemical reactions but this is not the case for the reduction where a dissociation of one or both $\mathrm{NH}_{3}$ axial ligands is proposed to occur prior to electron transfer, thus leading to several competing reduction pathways, one for the six-coordinate complex which is the most difficult to reduce and located at $E_{1 / 2}$ values more negative than $-1.0 \mathrm{~V}$ vs. SCE and the others for the five- and/or four-coordinate species which generate the $\mathrm{Co}^{1}$ corrole at potentials as positive as -0.07 to $-0.26 \mathrm{~V}$ as seen in Figure 8.

Evidence for dissociation of the $\mathrm{NH}_{3}$ ligand(s) prior to electron transfer is given in part by the shape of the current voltage curves which is consistent with a coupled chemical reaction prior to electron transfer (an electrochemical CE mechanism), in part by the fact that the first (ill-defined) reduction potentials of the bis- $\mathrm{NH}_{3}$ complexes in Figure 8 are almost identical to the well-defined $E_{1 / 2}$ values for the same cobalt corroles bearing a single DMSO axial ligand in their synthesized air stable form (Figure 7), namely, $-0.19 /-0.20 \mathrm{~V}$ for $2 \mathrm{NH}_{3}$ and $2 \mathrm{DMSO},-0.11 \mathrm{~V}$ for $3 \mathrm{NH}_{3}$ and $3 \mathrm{DMSO}$ and $-0.26 /-0.27 \mathrm{~V}$ for $4 \mathrm{NH}_{3}$ and $4 \mathrm{DMSO}$ (see Figure 7 and Table 5), and in part by the current voltage curves for $1 \mathbf{N H}$, to $\mathbf{4} \mathrm{NH}_{3}$ obtained in $\mathrm{CH}_{2} \mathrm{Cl}_{2}$ containing excess $\mathrm{NH}_{3}$ added in the form of $\mathrm{NH}_{4} \mathrm{OH}$.

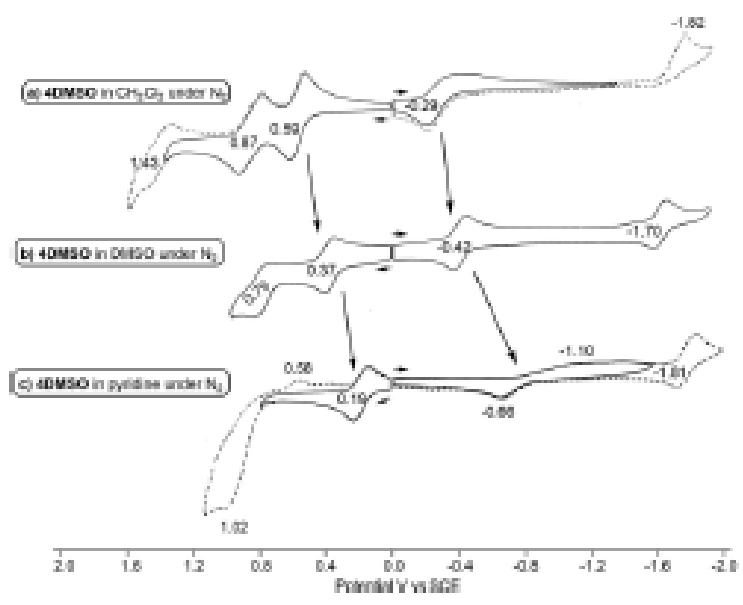

Figure 9. Cycic voltammograms of 4 DMSO in a) $\mathrm{CH}_{2} \mathrm{Cl}_{2}$ b) DNSO and c) pyridine containing $0.1 \mathrm{M}$ TBAP. 
Examples of cyclic voltammograms under these later solution conditions are given in Figure $S \mathbf{8}$ for $\mathbf{2} \mathbf{N H}_{3}, \mathbf{3} \mathbf{N H}_{3}$ and $\mathbf{4} \mathrm{NH}_{3}$. For all three corroles, the half-wave potentials of the two oxidations are the same as in the $\mathrm{CH}_{2} \mathrm{Cl}_{2}$ solvent without added $\mathrm{NH}_{3}$ (Figure 8), consistent with the proposed [(Cor)Co(NH$\left.H_{3}\right]^{\alpha / 4}$ redox process. However, when $\mathrm{NH}_{3}$ is added to solution, a diminished current intensity is seen in the first reduction peak as the equilibrium is shifted towards the harder to reduce bis-ligated form of the corrole in solution.

As mentioned above, the average HOMO-LUMO gap of the four mono-DMSO adducts $1 \mathrm{DMSO}$ to $4 \mathrm{DMSO}$ decreases from $825 \mathrm{mV}$ in $\mathrm{CH}_{2} \mathrm{Cl}_{2}$ (Figure 57 ) to $705 \mathrm{mV}$ in DMSO (Figure 7) and the gap decreases even further for the bis- $\mathrm{NH}_{\mathrm{y}}$ adducts where the separation between the first oxidation and first reduction is $330 \mathrm{mV}$ for $\mathbf{2} \mathrm{NH}_{3}$ in $\mathrm{CH}_{2} \mathrm{Cl}_{2}$ and $310 \mathrm{mV}$ for $\mathbf{4} \mathbf{N H}_{3}$ under the same solution conditions (see Figure 8). In each case, the decrease in the measured gap is attributed for the most part to a shift of the HOMO towards an easier oxidation. As shown in Figure 9, the measured $E_{1 / 2}$ value for the one-electron abstraction of $4 \mathrm{DMSO}$ varies from 0.59 to $0.37 \mathrm{~V}$ upon going from $\mathrm{CH}_{2} \mathrm{Cl}_{2}$ to DMSO and from 0.37 to $0.19 \mathrm{~V}$ upon going from DMSO to pyridine.

\section{Spectroelectrochemistry}

The singly oxidized and singly reduced forms of mono-DMSO and bis-ammonia corroles were characterized by thin-layer UV/ Visible spectroelectrochemistry and examples of the resulting spectral changes are illustrated in Figure 10 for compounds $4 \mathrm{DMSO}$ and $\mathbf{4} \mathrm{NH}_{\mathbf{3}}$ under different solution conditions. The a) 1 st oxidation

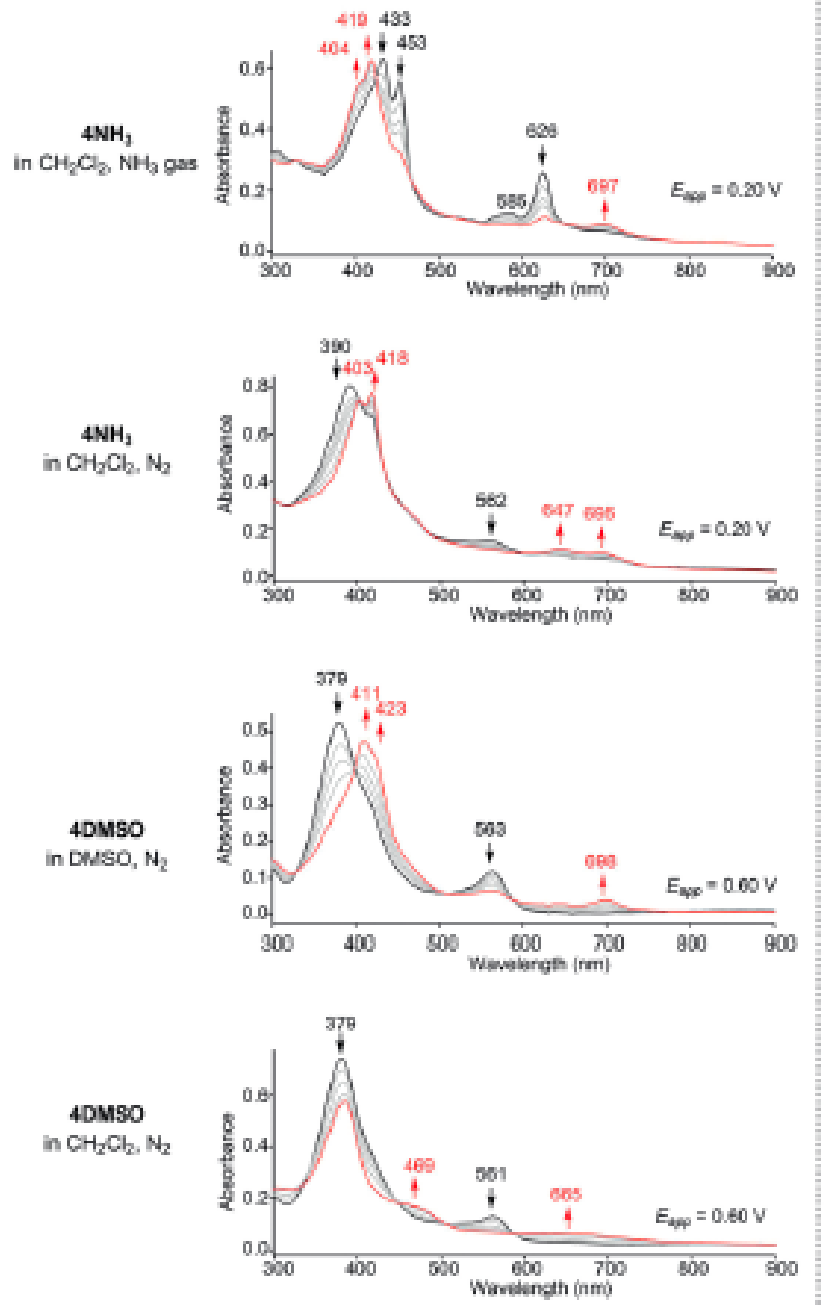

b) 1st reduction
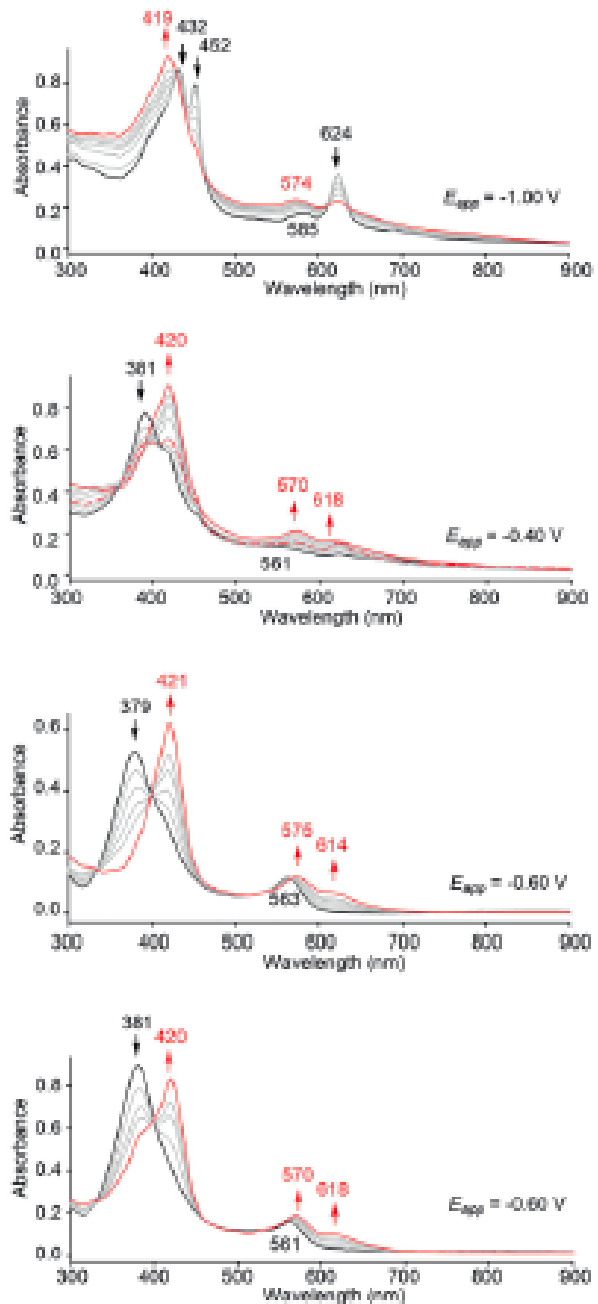

Figure 10. UVNisible spectra of a) the first cuidations and b) the first reductions for 4 DMSO under controlled potentials in different solution condition containing $0.1 \mathrm{M}$ TBAP. 
spectral changes obtained during reduction of $4 \mathrm{DMSO}$ are essentially independent of solvent as shown in Figure $10 \mathrm{~b}$ where the Soret band of the neutral corrole shifts from $379 / 381$ to $420 / 421 \mathrm{~nm}$ and the single visible band at $561 / 563 \mathrm{~nm}$ of the unreduced compound is replaced by two visible bands located between 570 and $618 \mathrm{~nm}$ after the addition of one-electron.

The spectrum of [ $4 \mathrm{DMSO}]^{-}$is assigned as containing an unligated $\mathrm{Co}^{\prime l}$ central metal ion and virtually the same UV/Visible spectrum is obtained after the reduction of $\mathbf{4} \mathbf{N H}$, in $\mathrm{CH}_{2} \mathrm{Cl}_{2}$ under an $\mathrm{N}_{2}$ or $\mathrm{NH}_{3}$ atmosphere, thus suggesting a similar square planar $\mathrm{CO}^{\mathrm{N}}$ electroreduction product. However, as mentioned earlier in the manuscript, a partial dissociation of one or both $\mathrm{NH}_{3}$ ligands occurs for $4 \mathrm{NH}_{3}$ when dissolved in $\mathrm{CH}_{2} \mathrm{Cl}_{2}$ under $\mathrm{N}_{2}$ but the original bis- $\mathrm{NH}_{3}$ adduct can be easily regenerated under an $\mathrm{NH}_{3}$ atmosphere or when $\mathrm{NH}_{4} \mathrm{OH}$ is added to solution. This is shown by the spectroscopic data in Figure 10 where the initial spectrum of $\mathbf{4} \mathrm{NH}_{3}$ under $\mathrm{N}_{2}$ is identical to that of four- or five-coordinate $4 \mathrm{DMSO}$ species but converts to that of the original bis- $\mathrm{NH}_{3}$ adduct when $\mathrm{NH}_{3}$ gas is bubbled through the solution. Under these conditions, the neutral sixcoordinate complex is characterized by a split Soret band at 432 and $452 \mathrm{~nm}$ and an intense six-coordinate marker band at $624 \mathrm{~nm}$ as shown in Figure 10. This spectrum is assigned to the $\mathrm{Co}^{\mathrm{II}}$ corrole which is then converted to its $\mathrm{Co}^{\mathrm{I}}$ form after controlled potential reduction at $-1.00 \mathrm{~V}$ in the thin layer cell. The same spectral product is obtained after the one-electron oxidation of $4 \mathrm{NH}_{3}$ under $\mathrm{N}_{2}$ or $\mathrm{NH}_{3}$ and this species, with a split Soret band between 403 and $419 \mathrm{~nm}$ and a broad $\mathrm{Q}$ band between 600 and $725 \mathrm{~nm}$ is assigned as a six-coondinate $\mathrm{Cl}^{\mathrm{II}}$ $\pi$-cation radical. Singly oxidized 4 DMSO has a similar spectrum in DMSO which is assigned to the bis-DMSO $\mathrm{CO}^{\mathrm{II}} \pi$-cation radical but this spectrum differs substantially from the spectrum of singly oxidized $4 \mathrm{DMSO}$ in $\mathrm{CH}_{2} \mathrm{Cl}_{2}$.

\section{Conclusions}

In summary, we have reported and characterized the electrochemistry and spectroscopic properties of mono-DMSO and bis-ammonia cobalt corroles in $\mathrm{CH}_{2} \mathrm{Cl}_{2}$, DMSO and $\mathrm{CH}_{2} \mathrm{Cl}_{2}$ $\mathrm{NH}_{4} \mathrm{OH}$ mixtures. The ligated DMSO axial ligand can be replaced by two ammonia molecules, shifting from a pentacoordinate cobalt corrole to a hexacoordinate one. The two ammonia molecules can be removed to smoothly access the tetra-coondinated the cobalt corrole, the active form of the compound able to selectively bind carbon monoxide. The formation of pentacoordinate cobalt corroles in the case of the DMSO and $\mathrm{CO}$ derivatives and hexacoordinate derivatives in the case of $\mathrm{NH}_{3}$ and pyridine axial ligands is observed experimentally and also observed by a DFT computational study. Thus, the theoretical predictions are in agreement with results from an X-ray determination on one compound and a variety of experimental data on all of the examined derivatives, which were characterized by electrochemistry, UVNisible and 'H NMR, spectroscopy and mass spectrometry.

\section{Experimental Section}

Materlals and Instrumentation: All chemicals and solvents were of the highest grade avallable and were used without further purff- cation. Dichloromethane $\left(\mathrm{CH}_{2} \mathrm{Cl}_{2}\right)$ and pyridine (Py) were purchased from Sigma Aldrich $\mathrm{Co}$ and used as recelved. Tetra-n-butyl-ammonlum perchlorate (TBAP), used as supporting electrolyte, was obtalned from Sigma Chemical Co.

Silica gek 60 (70-230 and 230-400 mesh, Sigma Aldrich) were used for column chromatography. Reactions were monitored by thinlayer chromatography, UV/Visible spectroscopy and mass spectrometry. $\mathrm{CDCl}_{3}$ was used as a solvent for ${ }^{1} \mathrm{H}$ NMR spectra which were reconded on a Eruker AVANCF III spectrometer ( $500 \mathrm{MHZ}$ ). The measurements were made at the PACSMUB-WPCM technological platform, which relles on the "Institut de Chimle Moleculaire de l'Untversite de Bourgogne" and Wellence "TM", a Eurgundy University private subsidlary. Chemical shifts were expressed in ppm. For 1DMSO-4DMSO, $\mathrm{NH}_{3}$ or $\mathrm{N}_{2} \mathrm{H}_{4} \mathrm{H}_{2} \mathrm{O}$ was added to enhance resolution of the spectra. Mass spectra were recorded on a Eruker Ultraflex Extreme MALDI Tandem TOF Mass Spectrometer using dithranol as the matrtx or on a LTQ Orbitrap XL. (Thermo) Instrument In the ESI mode (for the HRMS spectra). Low-resolution mass spectra (LRMS) were reconded on a Thermo Sclentfic" MSQ Plus" single quadrupole mass spectrometer equipped with an electrospray lonlzation (ESI) source. All LRMS mass spectra were reconded in the positive mode $\left(\mathrm{ESI}^{+}\right)$using the following parameters: "full scan", 250-1250 a.m.u, data type: centrold, needle voltage: $3.0 \mathrm{kV}$, detector voltage: $1100 \mathrm{~V}$, probe temperature: $350^{\circ} \mathrm{C}$, cone voltage: 10 $\mathrm{V}$ or $75 \mathrm{~V}$ and scan time: $1 \mathrm{~s}$. Sample preparation: Stock solution (1 mg/mL) of cobalt corroles were prepared in $\mathrm{CH}_{3} \mathrm{CN}$. Dilution by a factor $\times 20$ was achleved in $\mathrm{CH}_{3} \mathrm{CN}_{2} \mathrm{H}_{2} \mathrm{O}(2-1$, v/v) and the resulting solution (Ca. $600 \mu \mathrm{L}$ ) was directly analyzed by ESH-MS (direct infusion mode with a syringe pump, cone voltage: 75 V). To assess the chelation of DMSO and $\mathrm{NH}_{3}$ molecules, $2 \mu \mathrm{L}$ of an aq. DMSO solution $\left(25 \%\right.$ in water, $\mathrm{v} / \mathrm{V}$ ) or $\mathrm{NH}_{4} \mathrm{OH}$ was added to a dilute sample prior to injection through a direct infusion mode (cone voltage: $10 \mathrm{~V}$ ).

Infrared spectra were reconded in the solld state on an FT IR Eruker Vertex $70 \mathrm{v}$, using KEr pellets. UV/Misible spectra were recorded with a Hewlett-Packand Model 8453 dlode array spectrophotometer or with a Varlan Cary 50 . Cydic voltammetry was carried out at $298 \mathrm{~K}$ at $100 \mathrm{mV} / 5$ sweep rate using an EGeG Princeton Applied Research 173 potentiostat/galvanostat. A three-electrode system was used for cyclic voltammetric measurements and consisted of a glassy carbon working electrode, a platinum counter electrode and a saturated calomel reference electrode (SCF). The SCE was separated from the bulk of the solution by a fritted glass bridge of low poros. Ity which contained the solvent/supporting electrolyte mixture. Thin-layer UV/Visible spectroelectrochemical experiments were performed with a commenclal spectroelectrochemical cell purchased from PIne Instrument Inc. Potentlals were applied and monitored with an EGSG PAR Model 173 potentiostat. High purity $\mathrm{N}_{2}$ from Trigas was used to deoxygenate the solution and a stream of nitrogen was kept over the solution during each electrochemical and spectroelectrochernical experiment. Thermogravimetric (TGA) analyses were reconded using a Netzsch STA 409 PC thermal analyzer. The samples (approximately $7.0 \mathrm{mg}$ ) were heated from 298 to 1273 $\mathrm{K}$ with a heating rate of $5 \mathrm{~K} \mathrm{~min}^{-1}$ under a flow of nitrogen (30 $\mathrm{mL} \mathrm{min}^{-1}$ ) and axygen (10 $\left.\mathrm{mL} \mathrm{min}^{-1}\right)$.

DFT Computational Detalls: Quantum mechanics calculations were performed with the Gausslano9 software package. ${ }^{\mid m}$ Energy and forces were computed by density functional theory with the hybrid B3LYP exchange-comelation functional. Dispersion effects are Included through the empirical correction of Grimme with the Becke-yohnson dampling scheme. "I" Prevlous studles have shown that this level accurately reproduces geometrles and energles of cobalt corrole complexes. ${ }^{[15,13]}$ 
The solvent effects were modelled using a polartzable continuum model ${ }^{13}$ (PCM) as implemented in Gausslan09 to describe the dfchloromethane bulk medium. Geometrles were optimized and characterized with the $6-31+\mathrm{G} / \mathrm{d}$. p) basks sets for all atoms. Frequency calaulations were performed to ensure the absence of any imaglnary frequencles on local minima, and the presence of only one imaginary frequency on transition states. Gibbs free energles were computed at $298 \mathrm{~K}$ and $1 \mathrm{~atm}$. using the electronic energles and frequencles computed at the $6-31+G(d$, p) level.

Synthesis of Free-base and Mono-DMSO Cobalt Corroles, General Procedure: The free-base corroles tris(2,6-dichlorophenyl) corrole (1H), 10-(4-methouycarbonylphenyl)-5,15-dimesitylcomole (2H), triphenylcorrole (3H), 10-(2,4,6-trimethoxyphenyl)-5,15-drmesitylcorrole $(\mathbf{4 H})$ were synthesized acconding to procedures reported by Gryko and co-workers. ${ }^{\left[{ }^{5}\right]}$ Each free-base corrole, $\mathbf{1 H}, \mathbf{2 H}$ $3 \mathbf{H}$ or $\mathbf{4 H}$, (1.0 equiv.) was added to a solution of cobalt acetate tetrahydrate ( $47 \mathrm{mg}, 189 \mu \mathrm{mol}, 12$ equiv.) with DMSO $(20 \mathrm{~mL}$ ) in a round-bottomed flask after which the reaction mbture was stirned at $80^{\circ} \mathrm{C}$ for 40 minutes and then cooled to room temperature. The crude mbxture, Crude-Co, was poured into a cold $\mathrm{NaCl}$ aqueous solution $(0.8 \mathrm{M})$, the resulting suspension was filtered, and the solld was washed five times with water and dried ovemight in vacuo. The obtained dark red powder was characterized as the monoDMSO ligated complex 1DMSO, 2DMSO, 3DMSO or 4DMSO.

Synthesis of Bis- $\mathrm{NH}_{2}$ Cobalt Corroles: The crude mbxture, CrudeCo, obtained in the previous metalation step, was dissolved in $150 \mathrm{~mL}$ of dichloromethane, the organic phase washed four times (100 mL each) with an aqueous $0.4 \mathrm{M}$ ammonla solution, followed by addition of five drops of $25 \%$ aqueous ammonla to the solution. Methanol $(50 \mathrm{~mL}$ ) was added to the organic phase and dichloromethane removed, affording the desired product. The solld was then filtered and dried ovemight. A dark green powder was obtained and characterized as the bis- $\mathrm{NH}_{3}$ ligated cobalt corrole $1 \mathrm{NH}_{2}$ $2 \mathrm{NH}_{3}, 3 \mathrm{NH}_{2}$ or $\mathbf{4} \mathrm{NH}_{2}$.

$\left(\mathrm{Cl}_{2} \mathrm{Ph}\right)_{2} \mathrm{CorCo}(\mathrm{DMSO})$ (1DMSO)t $89 \%$ yleld (124 mg). Uv/Vlsible (toluene, 1\% DMSO) $\lambda_{\max }\left(\varepsilon \times 10^{-3} \mathrm{~L}_{\mathrm{mol}} \mathrm{m}^{-1} \mathrm{~cm}^{-1}\right) 381$ (51.9\%, 570 (10.6) nm. ' $\mathrm{H}$ NMR [500 MHz, CDCl, $\left.+\mathrm{NH}_{\mathrm{g}}(\mathrm{g})\right]: \delta=9.13$ (d, ${ }^{3} \mathrm{~J}_{\mathrm{rH}}=$ $4.1 \mathrm{~Hz}, 2 \mathrm{H}$ ), $8.62\left(\mathrm{~d},{ }^{3} J_{\text {pur }}=4.7 \mathrm{~Hz}, 2 \mathrm{H}, 8.52\left(\mathrm{~d},{ }^{3} \mathrm{~J}_{\mathrm{H}}=4.1 \mathrm{~Hz}, 2\right.\right.$ H), $8.49\left(\mathrm{~d},{ }^{3} J_{M(r)}=4.7 \mathrm{~Hz}, 2 \mathrm{H}\right), 7.74\left(\mathrm{~d},{ }^{2} J_{r M}=8.6 \mathrm{~Hz}, 6 \mathrm{H}\right), 7.64$ 7.59 (m, 3 H), 2.60 (s, $6 \mathrm{H}),-6.59$ (s, $6 \mathrm{H}) \mathrm{ppm}$. MS (MALDHTOF $\mathrm{m} / \mathrm{z}=785.73$ [M - DMSO]', 785.89 calcd. for $\mathrm{C}_{37} \mathrm{H}_{17} \mathrm{Cl}_{6} \mathrm{CoN}_{4}$. HR-MS $($ EST): $m / z=785.8933$ [M - DMSO] 7855.8911 calcd. for $\mathrm{C}_{7} \mathrm{H}_{1} \mathrm{Cl}_{6} \mathrm{CON}_{4}$. DMSO content by TGA: $\Delta /$ (calcd. for 1 DMSO ligated $)=11.46 \%(10.10 \%), T_{\text {onsot }}=124^{\circ} \mathrm{C}, \mathrm{T}_{\text {end }}=225^{\circ} \mathrm{C}$

$\left(\mathrm{Cl}_{2} \mathrm{Ph}\right)_{2} \mathrm{CorCo}\left(\mathrm{NH}_{2}\right)_{2}\left(\mathrm{NNH}_{2}\right) \mathrm{t} 79 \%$ yleld $(102 \mathrm{mg})$. UV/Vislble (toluene, $\left.1 \% \mathrm{NH}_{4} \mathrm{OH}\right): \lambda_{\max }\left(\varepsilon \times 10^{-3} \mathrm{~L}_{\mathrm{mol}} \mathrm{m}^{-1} \mathrm{~cm}^{-1}\right) 440$ (93.2). 451 (87.3) 514 (5.5), 589 (19.1), 617 (32.7) nm. ' $\mathrm{H}$ NMR [500 MHz, CDCl $+\mathrm{NH}_{y}$ (g)): $\delta=9.14$ (d, $\left.{ }^{3} h_{h(H}=4.1 \mathrm{~Hz}, 2 \mathrm{H}\right), 8.62$ (d, ${ }^{3} S_{\mathrm{hH}}=4.6 \mathrm{~Hz}, 2 \mathrm{Hl}$

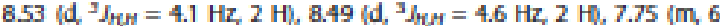
H), $7.62(\mathrm{~m}, 3 \mathrm{H}),-6.61(\mathrm{~s}, 6 \mathrm{H}) \mathrm{ppm}$. MS (MALDH-TOF) $\mathrm{m} / \mathrm{z}=785.77$ $\left[\mathrm{M}-2 \mathrm{NH}_{3}\right]^{+}, 785.89$ calcd. for $\mathrm{C}_{3,} \mathrm{H}_{1} \mathrm{Cl}_{6} \mathrm{CON}_{4}$. MS (ESI) $\mathrm{m} / \mathrm{z}=820.30$ $\left[\mathrm{M}^{+}\right.$; 819.94 calcd. for $\mathrm{C}_{27} \mathrm{H}_{27} \mathrm{Cl}_{8} \mathrm{CoN}_{\mathrm{c}}$. HR-MS (ESI): $\mathrm{m} / \mathrm{z}=785.8943$ $\left[\mathrm{M}-2 \mathrm{NH}_{3}\right]^{+} ; 785.8911$ calcd. for $\mathrm{C}_{3 \gamma} \mathrm{H}_{17} \mathrm{Cl}_{6} \mathrm{CoN}_{6} . \mathrm{NH}_{3}$ content by TGA: $\Delta m$ (calcd. for $2 \mathrm{NH}_{3}$ ligated) $=4.66 \%(4.16 \%), T_{\text {onet }}=113^{\circ} \mathrm{C}$ $T_{\text {med }}=176^{\circ} \mathrm{C}, \mathbb{I R}: \bar{v}=3360,3260 \mathrm{~cm}^{-1}$.

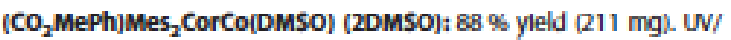
Visible (toluene, $1 \%$ DMSO): $\lambda$ max $\left(E \times 10^{-3} \mathrm{~L}^{-1} \mathrm{~mol}^{-1} \mathrm{~cm}^{-1}\right) 383(62.9)$ 563 (13.1) nm. ' $\mathrm{H}$ NMR [500 MHz, $\mathrm{CDCl}_{3}+\mathrm{NH}_{3}$ (g)]: $\delta=8.98$ (d.

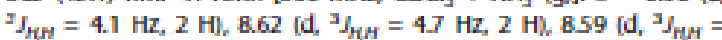
$4.7 \mathrm{~Hz}, 2 \mathrm{H}), 8.42\left(\mathrm{~d},{ }^{3} J_{\mathrm{Hut}}=4.1 \mathrm{~Hz}, 2 \mathrm{H}\right), 8.33\left(\mathrm{~d},{ }^{3} S_{\text {hy }}=7.9 \mathrm{~Hz}, 2\right.$ H), $8.26\left(\mathrm{~d},{ }^{3} J_{\mathrm{hur}}=7.9 \mathrm{~Hz}, 2 \mathrm{H}\right), 7.22(\mathrm{~s}, 4 \mathrm{H}), 4.02(\mathrm{~s}, 3 \mathrm{H}), 2.56(\mathrm{~s}, 6$
H). $2.55(5,6 \mathrm{H}), 1.86(5,12 \mathrm{H}),-6.68(5,6 \mathrm{H})$ ppm. MS (MALDHTOF) $\mathrm{m} / \mathrm{z}=723.75[\mathrm{M}-\mathrm{DMSO}]^{+}, 724.22 \mathrm{calcd}$. for $\mathrm{C}_{45} \mathrm{H}_{37} \mathrm{CoN}_{4} \mathrm{O}_{2}$. MS (ESD) $\mathrm{m} / \mathrm{z}=802.30[\mathrm{M}]^{+} ; 80224$ calcd. for $\mathrm{C}_{47} \mathrm{H}_{4} \mathrm{CON}_{4} \mathrm{O}_{3} \mathrm{~S}$. HR-MS $(E S D): m / z=7242263$ [M - DMSO] ${ }^{+}$, 7242243 calcd for $\mathrm{C}_{45} \mathrm{H}_{37} \mathrm{CON}_{4} \mathrm{O}_{7}$. DMSO content by TGA: $\Delta m$ (calcd. for 1 DMSO ligated $)=1229 \%(10.78 \%), T_{\text {mant }}=144^{\circ} \mathrm{C}, \mathrm{T}_{\text {mend }}=208^{\circ} \mathrm{C}$

$\left(\mathrm{CO}_{2} \mathrm{MePh}_{2} \mathrm{Mes}_{2} \mathrm{CorCo}\left(\mathrm{NH}_{2}\right)_{2}\left(2 \mathrm{NH}_{3}\right): 94 \%\right.$ yleld $(151 \mathrm{mg})$. UV/Vlstble (toluene, $\left.1 \% \mathrm{NH}_{2} \mathrm{OH}\right): \lambda_{\text {max }}\left(\mathrm{E} \times 10^{-3} \mathrm{~L}^{-1} \mathrm{~mol}^{-1} \mathrm{~cm}^{-1}\right) 439$ (53.2), 461 (58.9), 514 (8.2), 584 (93), 623 (25.0) nm. ${ }^{1} \mathrm{H}$ NMR [500 MHz, $\mathrm{CDCl}_{3}+\mathrm{NH}_{3}$ (g)) $\delta=9.05\left(\mathrm{~d}^{3}\right)_{\mathrm{HM}}=4.1 \mathrm{~Hz}, 2 \mathrm{~Hz}, 8.68\left(\mathrm{~d}^{3}\right)^{3} J_{\text {HM }}=$ $4.6 \mathrm{~Hz}, 2 \mathrm{H}, 8.66\left(\mathrm{~d},{ }^{2} J_{H, M}=4.6 \mathrm{~Hz}, 2 \mathrm{H}\right), 8.49\left(\mathrm{~d}^{2}{ }^{2} J_{\text {HM }}=4.1 \mathrm{~Hz}, 2\right.$ H), $8.39\left(\mathrm{~d}^{3} J_{\text {HWH }}=8.2 \mathrm{~Hz}, 2 \mathrm{H}\right), 8.32\left(\mathrm{~d}^{3} \mathrm{~J}_{\text {HUH }}=8.2 \mathrm{~Hz}, 2 \mathrm{H}\right), 7.26(\mathrm{~s}$, $4 \mathrm{H}), 4.07(\mathrm{~s}, 3 \mathrm{H}), 2.61(\mathrm{~s}, 6 \mathrm{H}), 1.90(\mathrm{~s}, 12 \mathrm{H}),-6.61(\mathrm{~s}, 6 \mathrm{H}) \mathrm{ppm}$. MS (MALDI-TOF) $m / z=724.88\left[\mathrm{M}-2 \mathrm{NH}_{3}\right]^{+}, 724.22$ calcd. for $\mathrm{C}_{45} \mathrm{H}_{3} \mathrm{CON}_{4} \mathrm{O}_{2}$. MS (EST) $\mathrm{m} / 2=758.26$ [M] $^{+}, 758.28 \mathrm{calcd}$. for $\mathrm{C}_{45} \mathrm{H}_{4} \mathrm{CON}_{8} \mathrm{O}_{2}$. HR-MS (ESI): $m / z=724.2244\left[\mathrm{M}-2 \mathrm{NH}_{3}\right]^{+*}, 724.2243$ calcd. for $\mathrm{C}_{85} \mathrm{H}_{37} \mathrm{CoN}_{4} \mathrm{O}_{2} . \mathrm{NH}_{3}$ content by TGA: $\Delta m$ (Calcd. for $2 \mathrm{NH}_{3}$ ligated $)=5.41 \%(4.76 \%), \mathrm{T}_{\text {orent }}=100^{\circ} \mathrm{C}, \mathrm{T}_{\text {end }}=175^{\circ} \mathrm{C}$. IR: $\mathrm{V}=$ $3338,3257 \mathrm{~cm}^{-1}$

Ph, CorCo(DMSO) (3DMSO): $71 \%$ yleld (70 mg). Un/Visible (tolu-

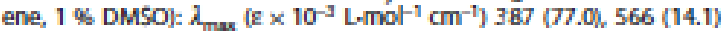
nm. ' $\mathrm{H}$ NMR [500 MHz, $\left.\mathrm{CDCl}_{3}+\mathrm{NH}_{y}(\mathrm{~g})\right] \mathrm{f} \delta=9.07\left(\mathrm{~d}^{3}\right)_{\mu r r}=4.1 \mathrm{~Hz}$, $2 \mathrm{H}), 8.91\left(\mathrm{~d},{ }^{3} J_{\mathrm{HH}}=4.7 \mathrm{~Hz}, 2 \mathrm{H}\right), 8.74-8.67(\mathrm{~m}, 4 \mathrm{H}), 8.22\left(\mathrm{~d},{ }^{3} J_{\mathrm{HH}}=\right.$ $7.4 \mathrm{~Hz}, 4 \mathrm{H}), 8.14\left(\mathrm{~d},{ }^{2} J_{\text {ruH }}=7.4 \mathrm{~Hz}, 2 \mathrm{H}\right), 7.72-7.56(\mathrm{~m}, 9 \mathrm{H}), 2.52$ (s, $6 \mathrm{H}),-6.47$ (5, $6 \mathrm{H}) \mathrm{ppm}$. MS (MALDl-TOF) $\mathrm{m} / \mathrm{z}=581.71 \mathrm{M}-$ DMSO] $^{+}, 582.12$ calcd. for $\mathrm{C}_{\mathrm{s} \gamma} \mathrm{H}_{22} \mathrm{CoN}_{4}$. MS (EST) $\mathrm{m} / \mathrm{z}=660.33[\mathrm{M}]^{+}$; 660.14 calcd. for $\mathrm{C}_{3} \mathrm{H}_{28} \mathrm{CON}_{4} \mathrm{OS}$. HR-MS (ESD): $m / z=582.1257$ [M DMSO] $]^{+}, 582.1249$ calcd. for $\mathrm{C}_{3 \gamma} \mathrm{H}_{2 z} \mathrm{CON}_{4}$. DMSO content by TGA: $\mathrm{Am}$ (calcd. for $1 \mathrm{DMSO}$ ligated) $=10.53 \%(11.20 \%), \mathrm{T}_{\mathrm{onat}}=120^{\circ} \mathrm{C}$, $T_{\text {end }}=193^{\circ} \mathrm{C}$

$\mathrm{Ph}_{2} \mathrm{CorCo}\left(\mathrm{NH}_{3}\right)_{2}\left(3 \mathrm{NH}_{3}\right) \mathrm{t} 80 \%$ yleld (237 mg). UV/Vk (toluene, $1 \%$ $\left.\mathrm{NH}_{4} \mathrm{OH}\right): \lambda_{\max }\left(\mathrm{E} \times 10^{-3} \mathrm{Lmol}^{-1} \mathrm{Cm}^{-1}\right) 436(29.0), 455(25.0), 526$ (3.00), 585 (4.2), 629 (12.0) nm. ' ${ }^{1} \mathrm{H}$ NMR [500 MHz, $\mathrm{CDCl}_{2}+\mathrm{NH}_{3}$ (g)]: $\delta=9.08\left(\mathrm{~d}^{3} J_{\mathrm{HH}}=3.2 \mathrm{~Hz}, 2 \mathrm{H}\right), 8.91\left(\mathrm{~d},{ }^{3} J_{\mathrm{rMH}}=4.2 \mathrm{~Hz}, 2 \mathrm{H}\right), 8.72$ $(\mathrm{m}, 4 \mathrm{H}), 8.23\left(\mathrm{~d}^{3} \mathrm{~J}_{\mathrm{MH}}=7.4 \mathrm{~Hz}, 4 \mathrm{H}\right), 8.15\left(\mathrm{~d},{ }^{3} J_{\mathrm{HMr}}=7.4 \mathrm{~Hz}, 2 \mathrm{H}\right)$, 7.64 (m, $9 \mathrm{H}),-6.46$ (S, $6 \mathrm{H}$ ) ppm. MS (MALDHTOF) $\mathrm{m} / \mathrm{z}=582.64$ [M $\left.-2 \mathrm{NH}_{3}\right]^{+-}, 582.13$ calcd. for $\mathrm{C}_{37} \mathrm{H}_{22} \mathrm{CON}_{4}$. MS (ESI) $\mathrm{m} / \mathrm{z}=616.20[\mathrm{M}]^{+}$; 616.18 calcd. for $\mathrm{C}_{33} \mathrm{H}_{29} \mathrm{CON}_{2}$. HR-MS (ESD): $\mathrm{m} / \mathrm{z}=582.1252$ [M $\left.2 \mathrm{NH}_{3}\right]^{+}, 582.1249$ calcd. for $\mathrm{C}_{37} \mathrm{H}_{22} \mathrm{CoN}_{4}$. $\mathrm{NH}_{3}$ content by TGA: $\Delta \mathrm{m}$ (calcd. for $2 \mathrm{NH}_{3}$ ligated) $=4.45 \%(4.72 \%), \mathrm{T}_{\text {ornet }}=100^{\circ} \mathrm{C}, \mathrm{T}_{\text {end }}=$ $172{ }^{\circ} \mathrm{C}$ IR: $\mathrm{v}=3338 \mathrm{~cm}^{-1}, 3257 \mathrm{~cm}^{-1}$. IR: $3413,3252 \mathrm{~cm}^{-1}$

[(OMe) ${ }_{2}$ Ph]Mes ${ }_{2}$ CorCo(DMSO) (4DMSO): $83 \%$ yleld (193 mg). UV/ Vislble (toluene, $1 \%$ DMSO): $\lambda_{\max }\left(\varepsilon \times 10^{-3} \mathrm{~L}^{-1} \mathrm{~mol}^{-1} \mathrm{~cm}^{-1}\right) 380$ (63.4), 564 (14.1) nm. ${ }^{1} \mathrm{H}$ NMR ( $500 \mathrm{MHz}_{2} \mathrm{CDCl}_{3}+1 \% \mathrm{NH}_{2} \mathrm{NH}_{2} \cdot \mathrm{H}_{2} \mathrm{O}$ ): $\delta=$

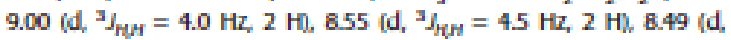
$\left.{ }^{3} J_{\text {tur }}=4.5 \mathrm{~Hz}, 2 \mathrm{H}\right), 8.44\left(\mathrm{~d},{ }^{3} J_{\text {mur }}=4.0 \mathrm{~Hz}, 2 \mathrm{H}\right), 725(\mathrm{~s}, 4 \mathrm{H}), 6.54$ $(5,2 \mathrm{H}), 4.07$ (s, $3 \mathrm{H}), 3.48(5,6 \mathrm{H}), 2.60(\mathrm{~m}, 12 \mathrm{H}), 1.88(\mathrm{~s}, 12 \mathrm{H})$, -3.89 (s, 4 H) ppm. MS (MALDI-TOF) $m / 2=756.09$ [M - DMSO] $]^{+}$; 756.25 calcd. for $\mathrm{C}_{42} \mathrm{H}_{41} \mathrm{CON}_{2} \mathrm{O}_{3}$. MS (ESI) $\mathrm{m} / \mathrm{z}=834.34$ [M] ${ }^{+2}, 834.27$ calcd. for $\mathrm{C}_{48} \mathrm{H}_{4} \mathrm{CON}_{4} \mathrm{O}_{4}$ S. HR-MS (ESI): $\mathrm{m} / 2 \mathrm{z}=756.2507$ [M DMSO] ${ }^{+}$; 756.2505 calcd. for $\mathrm{C}_{46} \mathrm{H}_{41} \mathrm{CON}_{4} \mathrm{O}_{3}$. DMSO content by TGA: $\Delta m$ (calcd. for 1 DMSO ligated) $=9.88 \%(9.60 \%), T_{\text {anut }}=158{ }^{\circ} \mathrm{C}$, $T_{\text {end }}=233^{\circ} \mathrm{C}$

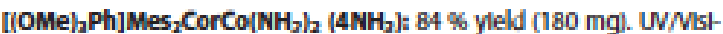
ble (toluene, $\left.1 \% \mathrm{NH}_{4} \mathrm{OH}\right)$ 453 (55.9), 514 (6.2), 585 (10.0), 624 (24.9) nm. 'H NMR (500 MHz, $\left.\mathrm{CDCl}_{3}+1 \% \mathrm{NH}_{2} \mathrm{NH}_{2}, \mathrm{H}_{2} \mathrm{O}\right)=9.05\left(\mathrm{~d}^{3} \mathrm{~J}_{\text {hur }}=4.1 \mathrm{~Hz}, 2 \mathrm{H}\right), 8.61$ (d, $\left.{ }^{3} J_{\text {res }}=4.5 \mathrm{~Hz}, 2 \mathrm{H}\right) 8.55\left(\mathrm{~d},{ }^{3} J_{\mathrm{HH}}=4.5 \mathrm{~Hz}, 2 \mathrm{H}\right), 8.49\left(\mathrm{~d},{ }^{3} J_{\mathrm{HeH}}=\right.$ $4.1 \mathrm{~Hz}, 2 \mathrm{H}), 7.29(\mathrm{~s}, 4 \mathrm{H}) 6.58(5,2 \mathrm{H}), 4.11(\mathrm{~s}, 3 \mathrm{H}), 3.52(5,6 \mathrm{H}), 2.64$ $(5,6 \mathrm{H}), 1.93$ (s, $12 \mathrm{H},-4.18(\mathrm{~s}, 4 \mathrm{H})$ ppm. MS (MALDH-TOF) $\mathrm{m} / \mathrm{z}=$ $756.08\left[\mathrm{M}-2 \mathrm{NH}_{3}\right]^{+}, 756.25$ calcd. for $\mathrm{C}_{46} \mathrm{H}_{41} \mathrm{CON}_{4} \mathrm{O}_{3}$. MS (ESI) $\mathrm{m} / \mathrm{z}=$ 
$790.30\left[\mathrm{M}^{+} ; 790.30 \mathrm{calcd}\right.$. for $\mathrm{C}_{46} \mathrm{H}_{47} \mathrm{CON}_{8} \mathrm{O}_{3}$. HR-MS (ESD): $\mathrm{m} / \mathrm{z}=$ $756.2507\left[\mathrm{M}-2 \mathrm{NH}_{3}\right]^{4}, 756.2505$ calcd for $\mathrm{C}_{4} \mathrm{H}_{41} \mathrm{CoN}_{4} \mathrm{O}_{3}$. $\mathrm{NH}_{3}$ content by TGA: $\Delta m$ (calcd. for $2 \mathrm{NH}_{3}$ ligated) $=3.12 \%(3.60 \%)$, Tonset $=$ $42^{\circ} \mathrm{C}, \mathrm{T}_{\text {mad }}=120^{\circ} \mathrm{C}$ IR: $\nabla=3357,3261 \mathrm{~cm}^{-1}$.

Crystal Structure Determination of $\mathbf{4 H}$ and $\mathbf{1 N H}_{\mathbf{2}}$ : Light violet needle-shaped crystak of free-base $\mathbf{4 H}$ were recrystallized from a mbxture of water and acetone by slow evaporation and a sultable crystal $(0.25 \times 0.20 \times 0.08) \mathrm{mm}^{2}$ was mounted with MITGEN holder oll on a Eruker DB VENTURE diffractometer and kept at $100(1) \mathrm{K}$ during data collection. For the cobalt corrole $\mathbf{1} \mathbf{N H}_{\mathbf{2}}$, clear dark violet plate-shaped crystals were obtalned from a mbxture of hexane and DCM by slow evaporation and a sultable crystal $(0.22 \times 0.20 \times 0.15]$ $\mathrm{mm}^{3}$ was selected for structure determination. Both crystals were examined with Olex $2^{1101}$ and the structures solved with the ShelXT ${ }^{[19]}$ structure solution program, using the Intrinsic Phasing solution method. The model was refined with version 2016/6 of ShelXL" ${ }^{\text {ne }}$ using least-squares minimization. Additional detalls are given in supporting information.

Crystal Data for Free-base Corrole $4 \mathrm{H}_{\mathrm{t}} \mathrm{C}_{42} \mathrm{H}_{50} \mathrm{~N}_{8} \mathrm{O}_{4}, M_{\mathrm{r}}=758.93$, monoclinic, $P Z_{1} / c$ (No. 14), $a=7.5501(2) A, b=24.8197(8) \AA A, c=$ $21.8942(7) A, \beta=97.165(2)^{\circ}, a=\gamma=90^{\circ}, V=4070.7(2) A^{3}, T=$ $100(1) K, Z=4, Z^{\prime}=1, \mu\left(C u-K_{p}\right)=0.624,35965$ reflections measured, 7175 unique $\left(R_{\text {int }}=0.0962\right)$ which were used in all calculations. The final wR was 0.1167 (all data) and $R_{1}$ was $0.0556[l>2(j)]$

Crystal Data for $1 \mathrm{NH}_{2}: \mathrm{C}_{7} \mathrm{H}_{53} \mathrm{Cl}_{12} \mathrm{CO}_{2} \mathrm{~N}_{12}, \mathrm{M}=1689.57$, monodinic, $P 2_{1} / C$ (No. 14), $a=12.7201$ (5) $A, b=7.3022(3) A, c=38.3166(16) \AA$, $\beta=94.677(2)^{\circ}, a=\gamma=90^{\circ}, V=35472(3) A^{3}, T=100(1) K, Z=2$, $Z^{\prime}=0.5, \mu\left(\mathrm{Cu}-\mathrm{K}_{\mathrm{a}}\right)=8.272,21938$ reflections measured, 6253 unique $\left(R_{m i n}=0.0825\right)$ which were used in all calculations. The final $w R_{2}$ was 0.2447 (all data) and $R_{1}$ was $0.0955[V>2(0)]$.

Supporting Information (see footnote on the first page of this artide): UV/Visible spectra, cyclic voltammograms, MALDI/TOF MS spectra, ${ }^{1} \mathrm{H}$ NMR, ESR spectra and CIF file giving crystallographic. data for compound $1 \mathrm{NH}_{3}$ and compound free-base corrole $\mathbf{4 H}$, selected bond lengths and angles as well as XYZ coondinates (DFT calaulations).

CCDC 1812155 (for $\mathbf{1} \mathbf{N H}_{2}$ ), and 181709 (for free-base corrole $\mathbf{4 H}$ ) contain the supplementary crystallographic data for this paper These data can be obtalned free of charge from The Cambridge Crystallographic Data Centre

Notes

The authors declare no competing financial interest.

Conflict of interest

The authors declare no conflict of interest.

\section{Acknowledgments}

This work was supported by the Robert A. Welch Foundation (K. M. K. Grant E-680). Support was prowided by the Centre National de la Recherche Scientifique (CNRS) (UMR UB-Centre National de la Recherche Scientifique (CNRS) 6302), the "Universite de Bourgogne Franche-Comte", the FEDER-FSE Bourgogne 2014/2020 (European Regional Development Fund) and the "Conseil Régional de Bourgogne" through the PARI II CDEA project and the JCE program. We are thankful to Mrs. Sandrine
Pacquelet for technical assistance and W. Ryan Osterloh for experimental help. ANR is granted for financial support (CO3SENS). The authors wish also to warmly thank Prof. Anthony Romieu (IUF, UBFC, ICMUB, UMR CNRS 6302) for recording the LRMS ESI spectra of cobalt corrole complexes.

Keywords: Cobalt - DMSO binding - Ammonia binding Electrochemistry - Coordination chemistry

(1] a) J. F. B. Barsta, M G. P. M. S. Noves, M. A. F. Faustino, A. C. Tomé and I.A. S. Gavaleiro, Chem $\operatorname{Rex} 2017,117,3192-3253$; b) Y. Fang, Z. Ou and K. M. Kadish, Chem. Rev. 2017, 117, 3377-3419; c) A. Ghosh, Chem. Rav. 2017, 117, 3798-3881; d) R. Orlowski. D. Gryko and D. T. Gryko, Chem. Dev. 2017, 117, 3102-3137; e) R. Poolesse, S. Naedis, D. Monti, M. Stefanelli and C Di Natale, Chem. Rev. 2017, 117, 2517-2583; f) R. D. Tea, 1 Y. Hwang. J. Tormini, Z. Gross and H. B. Gray, Chem. Rex 2017, 117, 27112729; g) W. Thang W. Lai and R. Caa, Chem. Rex. 2017, 117, 3717-3797.

[2] X. Jiang, W. Shan, N. Desbois, V. Quesneau, S. Brandes, E. Van Casmel. becke, W. R. Osterloh, V. BlondesurPatissisr, C. P. Gros and K. M. Kadish, New I. Chem. 2018, 42, 82200-8229.

[3] X. Jang, M. Naitana, N. Desbois, V. Qussnesu, S. Erandes, Y. Roussolin, W. Shan, W. R. Ostarloh, V. Elondesu-Patissier, C. P. Gros and K. M. Kadish, Inovg Chem 2018, 57, 1226-1241.

4] M. Vanotti, C Theron, S. Poisson, V. Quesneasu, M. Naitana, V. Soumann, 5. Brandis, N. Desbois, C. Gros, T.H. Tran-Thi and V. Elondesu-Patissier, Procosdings 2017, 1, 444.

(5] a) D. T. Gryko and B. Kosmarna, Org. Biomol Chem. 2003, 1, 350; b) B. Koszarns and D. T. Gryka, 1 Ong Chem. 2006, $71,3707-3717$.

6] S. Ganguly, I. Conradie, I. Bondix, K. I. Gagnon, L I. MoCormick and A. Ghosh, 1 Phys Chem. A 2017, 121, 9589-9598.

[7] a) R. Guilard, C. P. Gros, F. Eolse, F. Jerome, Z P. Ou J. G. Shao, I. Fischer, R. Woiss and K. M. Kadich, linarg. Chem. 2001, 40, 4845-4855; b) R. Guilard, F. Jirome, I. M. Barbe, C. P. Gros, Z. P. Ou, J. Shao, J. Fischer, R. Woiss and K. M. Kadish, linarg. Chem. 2001, 40, 4856-4805.

(8] F. P. A. Fabbiani, G. Buth, B. Dittrich and H. Sowa, CrystEngComm 2010 12, 2541-2550.

[9] L. Saltsman, L. Goldberg and Z Gross, Orglest. 2015, 17, 3214-3217.

[10] M. J. Frisch, G. W. Trucks, H. B. Schlogel, G. E. Scuseria, M. A. Robh, J. R. Cheesemsn, G. Scalmari, V. Barone, B. Mornucci, G. A. Potersson, H. Ns katsuj, M. Caricato, X. Li, H. P. Hratchian, A. F. Izmaylov, J. Bloino, G. Zheng, 1 L Sonnenberg, M. Hads, M. Ehara, K. Toyota, R. Fukuda, I. Hasegawa, M. Ishida, T. Nakajima, Y. Honda, Q. Kitsa, H. Nakai, T. Vrewen, 1 A Montgomery, Ir, J. E. Poralta, F. Ogliarn, M. Bearpark, 1 J. Heyd, E. Brothors, K. N. Kudin, V. N. Staroworov, R. Kobsyochi, I Nommand K. Raghavochari, A. Rendell, J. C. Burant, S. S. lyengax, 1 Tomssi, M. Cossi, N. Rega, N. J. Millsm, M. Klene, 1. E. Knox, J. B. Cross, V. Bakken, C. Adama, J Jaramillo, R. Gomperts, R. E Stratmann, Q. Yaxyov, A. J. Austin, R. Cammi, C. Pomelli, J. W. Ochterski, R. L. Martin, K. Morokums, V. G. Zakrasweki, G. A. Voth, P. Salvodoc, 1. 1. Dannenberg, S. Dapprich, A. D. Dariok, O Farkas, 1. B. Foresman, 1 V. Ortiz, I. Gioslowski and D. 1. Fox in Gaussian 09, Revision D.01, Gassian, Inc, Wallingfand CT, 2009, Vol. 2009.

[11] a) S. Grimme, S. Ehrich and L Goerigk, L. Comput Chem. 2011, 32, 14561405; b) A. D. Becke and E. R. Johnson, L. Chern. Phys. 2005, 123, 154101.

[12] a) S. Ganguly, D. Renz, L. J. Giles, K. J. Gagnon, L 1 Mocomrick J. Con radie, R. Sarsingi and A. Ghosh, Inarg Chem. 2017, 56, 14788-14806; b) X. Sheng, H. Thso and L. Du, Sa. Alep. 2017, 7, 14536.

(13] a) B. Mennucri, E. Cancess and I. Tomasi, J. Phys. Chem. B 1997, 101, 10506 ; b] S. Miertus, E. Scrocco and 1 Tomas, 1. Chem. Phys. 1981, 55, 117.

[14] O. V. Dolomanov, L. J. Bourhis, R. J. Gildea, J. A. K. Howaed and H. Puschmsnn, I. Appl. Cyyst 2009, 42, 339-341.

[15] G. M. Sholdrick, Acta Cryst. 2015, A77, 3-8.

[16] G. M. Sholdrick, Acta Cyst. 2015, C71, 3-8.

Recaived: July 18, 2018 